Pamiętnik Literacki 2019, 1, s. 161-189

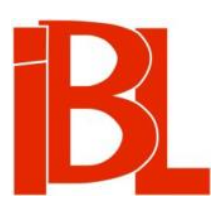

\title{
Przed nowym wydaniem dzienników Żeromskiego - losy autografów
}

\author{
Zdzisław Jerzy Adamczyk
}




\section{2. $\begin{array}{llllllllllllllllll} & \mathrm{M} & \mathrm{A} & \mathrm{T} & \mathrm{E} & \mathrm{R} & \mathrm{I} & \mathrm{A} & \mathrm{L} & \mathrm{Y} & \mathrm{I} & \mathrm{N} & \mathrm{O} & \mathrm{T} & \mathrm{A} & \mathrm{T} & \mathrm{K} & \mathrm{I}\end{array}$}

Pamiętnik Literacki CX, 2019, z. 1, PL ISSN 0031-0514

DOI: $10.18318 / \mathrm{pl} .2019 .1 .10$

ZDZISŁAW JERZY ADAMCZYK Uniwersytet Jana Kochanowskiego, Kielce

\section{PRZED NOWYM WYDANIEM DZIENNIKÓW ŻEROMSKIEGO - LOSY AUTOGRAFÓW}

Pełne wydanie dzienników Stefana Żeromskiego ukazało się - pół wieku temu dwukrotnie: najpierw w latach 1953-1956 w trzech opasłych tomach, pod kierunkiem, kolejno, Wacława Borowego, Stanisława Adamczewskiego i Jerzego Kądzieli ${ }^{1}$, powtórnie w latach 1963-1970, w siedmiu tomach, w ramach Dziet Żeromskiego pod redakcją Stanisława Pigonia ${ }^{2}$. W obu tych edycjach objaśnienia do tekstu przygotował Kądziela. W czasach późniejszych publikowane były tylko wybory z dzienników ${ }^{3}$, światło dzienne ujrzały także dwa tomiki - odnalezione już po zakończeniu edycji Dzieł $\iota^{4}$. Te dwa wydania, określone tutaj jako „pełne”, na dobrą sprawę takimi nie były. Dziś wiemy, że do naszych czasów zachowało się 18 tomików dziennika Żeromskiego, natomiast w pierwszej „pełnej” edycji znalazło się 15 tomików, w drugiej - 16. Wydania owe nie były pełne również z tego względu, że spore fragmenty tekstu dziennika zostały w nich usunięte - z powodów po części politycznych, głównie jednak obyczajowych. Wydanie pierwsze tymi „obyczajowymi” wykreśleniami zostało wprost zmasakrowane; wydanie drugie - poważnie okaleczone. Przygotowywana obecnie nowa edycja dzienników musi - w ciągu chronologicznym - zawrzeć wszystkie zachowane tomiki $z$ tekstem nieocenzurowanym.

Wiadomo także, iż swymi diarystycznymi zapiskami młody Żeromski zapełnił co najmniej 26 tomików, a to oznacza, iż do naszych czasów nie dochowało się minimum 8 notatników $z$ tekstem dziennika. Nim się zatem zacznie sposobić nową

$1 \quad$ S. Żeromski: Dzienniki. I: 1882-1886. Tekst przygot. W. Borowy, S. Adamczewski. Przypisy J. Kądziela. Warszawa 1953; Dzienniki. II: 1886-1887. Tekst przygot. S. Adamczewski. Przypisy J. Kądziela. Warszawa 1954; Dzienniki. III: 1888-1891. Tekst przygot., przypisy oprac. J. Kądziela. Warszawa 1956.

2 S. Żeromski: Dzienniki. Przedm., oprac. J. Kądziela. T. 1-6. Warszawa 1963-1966; T. 7: Dzienniki. Przypisy - słowniki - skorowidze. Oprac. J. Ką d zi ela. Warszawa 1970. Dzieta. Red.

S. Pigoń.

3 S. Że ro m s ki: Dzienniki. (Wybór). Oprac. J. Ką d zi i la. Wrocław 1980. BN I 238 (wyd. 2 w roku 2006 w 2 woluminach); Księga namiętności. Dzienniki intymne Stefana Żeromskiego. Wybór, oprac.

J. B e d n a row ski. Brzezia Łąka 2014.

4 S. Żeromski: Dzienników tom odnaleziony. $Z$ autografu do druku przygot., wstęp, przypisy

J. Kądziela. Warszawa 1973; Dziennik z wiosny 1891 roku. Oprac. Z. J. Ada m czyk,

Z. Golinn ski. Kielce 2000. Odbitka z „Kieleckich Studiów Filologicznych”. T. 14. 
edycję Dzienników, ustalać zakres i zasady modernizacji języka czy merytorycznych objaśnień do tekstu itd., itd., najpierw wypada prześledzić losy autografów - od roku 1882, gdy w najwcześniejszym tomiku dziennika pojawiły się pierwsze zapisy, poprzez szkolne i studenckie lata tułania się ich autora po stancjach i „kondycjach”, późniejsze liczne przeprowadzki do Nałęczowa, Warszawy, Krakowa, Zakopanego, Paryża i Konstancina, przez międzywojenne lata, kiedy tomiki dziennika były w posiadaniu Anny Żeromskiej - aż po dramatyczne dzieje wojenne i powojenne, gdy zostały wywiezione do Rzeszy Niemieckiej, stamtąd do Moskwy i wreszcie wróciły do Warszawy. Takie „śledztwo” jest potrzebne a nawet konieczne, gdyż zawarte $\mathrm{w}$ dotychczasowych publikacjach informacje na ten temat sa dalece, dalece niewystarczające, a nierzadko i odległe od prawdy, zarazem zaś zachowały się ważne a nie publikowane dotąd dokumenty, dzięki którym dzieje tomików z diarystycznymi zapiskami młodego Żeromskiego da się poznać o wiele gruntowniej - i lepiej zrozumieć, jak mogło dojść do tego, iż tak wiele tomików - prawie trzecia część całego zespołu - nie dotrwało do naszych czasów.

Osiemnastoletni uczeń piątej klasy kieleckiego gimnazjum zaczał prowadzić dziennik $19 \mathrm{~V}$ 1882. Od dawna pisał poezje i dramaty, nie kryjąc się nawet $\mathrm{z}$ tą swoją twórczością przed kolegami ${ }^{5}$, ale dopiero $19 \mathrm{~V} 1882$ poznaje podobnego do siebie „marzyciela i wierszokletę”, Edwarda Łuszczkiewicza - i ta znajomość wyzwala w nim chęć systematycznego przelewania na papier spostrzeżeń, myśli i uczuć. Odtąd niemal każdego dnia rejestruje owe zdarzenia i stany emocjonalne, lecz w miarę upływu czasu charakter tekstu się zmienia; dziennik przeobraża się w swego rodzaju literacki poligon doświadczalny przyszłego twórcy; zapisy w diariuszu - coraz obszerniejsze - stają się jakby ćwiczeniami w sztuce kreślenia ludzkich portretów, obrazowania świata, analizowania uczuć, konstruowania dialogów. Ta właśnie funkcja dziennika, taki cel dziennikowych zapisów zaczyna dominować nad innymi. Dla takiego celu dziennik potrzebny jest jednak Żeromskiemu tylko do chwili, gdy jego utwory nowelistyczne pokonuja barierę druku. Dziennikarskie korespondencje i artykuły, pojedyncze obrazki i „szkice etnograficzne” publikuje młody autor od końca roku 1899, ale na dobre wkracza do literatury w roku 1891, gdy „Głos” zamieszcza na swoich łamach cała serię jego opowiadań. I z końcem tegoż 1891 roku Żeromski dziennik zarzuca. W początkach roku 1892, zrezygnowawszy z dotychczasowych zajęć guwernerskich w Nałęczowie, wyjeżdża na kilka miesięcy do Galicji, rusza w pierwszą podróż zagraniczna - i teraz takim poligonem literackich ćwiczeń stają się jego listy do kochanej kobiety, do Oktawii Rodkiewiczowej, wkrótce narzeczonej, a niebawem żony. W styczniu 1892 Żeromski jeszcze dziennik prowadził. W liście pisanym w Wiedniu 16 I 1892 zapewniał Oktawię, że w dzien-

5 Także wcześniej prowadził Żeromski „coś w rodzaju pamiętniczka”. Wiemy o tym tylko tyle, ile sam ujawnił w dzienniku pod datą 13 X 1882: „Dawno już temu, bo w czwartej jeszcze klasie, pisałem coś w rodzaju pamiętniczka i wspomniałem tam o tym już dawniej odczuwanym uwielbieniu dla pana Bema. Razem z innymi i to doszło do rak profesora. Powiedział mi on wtenczas, o! dobrze pamiętam, co mi powiedział: "Mógłbym pochwałę wynurzoną dla mnie w pamiętniczku pańskim uważać za pragnienie przylizania mi się, bo piszesz pan pochwałę dla mnie i podajesz mi ją"." Tekst dziennika cytujemy na podstawie autografów. Bliższych informacji o tym „pamiętniczku” nie posiadamy. Uczniem czwartej klasy Żeromski był w roku szkolnym 1880/81. 


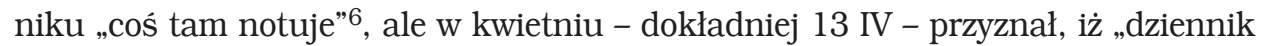
zarzucony czy zdegradowany do rzędu notesu, gdzie się zapisuje "winien" albo "wydał" - i rolę jego w funkcjonowaniu artystyczno-podróżniczo-recenzyjnym zastępują listy”7, na końcu listu z 26 V 1892 prosił zaś Oktawię: „Nie niszcz, Tutusiu, moich listów, bo teraz, gdy nie prowadzę dziennika, będę miał w nich dziennik"8. W maju 1892, równo 10 lat po pierwszym wpisie - przestaje dziennik kontynuować.

Notesy z zapisami dziennikowymi, podobnie jak autografy wielu swoich utworów, jak wszelkie otrzymywane listy, Żeromski starannie przechowywał - chociaż nie miał po temu warunków. Od dziewiętnastego roku życia był przecież - przez wiele lat - bezdomny. Jego ojciec trudnił się dzierżawieniem w Kieleckiem folwarków szlacheckich; gdy w roku 1883 zmarł, kontrakt w sprawie dzierżawy Ciekot został unieważniony, do ciekockiego dworku wprowadził się nowy dzierżawca, przyszły zaś pisarz i jego dwie siostry zostali - najdosłowniej - bez środków utrzymania i bez dachu nad głową. Przez szereg lat Żeromski żył w wynajmowanych mieszkaniach: w Kielcach na uczniowskiej stancji, w Warszawie w studenckich pokojach dzielonych do spółki z kolegami; gdy wyjeżdżał „na kondycję” do szlacheckich dworów, woził to swoje literackie archiwum $z$ sobą. Sam o tym parokrotnie mówi na kartach dziennika. Kiedy pod data 5 VI 1887 wyjawia, w jak skrajnej biedzie żyje w Warszawie, opisuje i swój studencki pokój, w którym - poza łóżkiem i stolikiem - nie ma mebli, jest natomiast półka $\mathrm{z}$ książkami:

Półka ta jest nader demokratycznego pochodzenia; była to paczka na mydło. Oderwałem jednę jej stronę, a resztę przybiłem gwoździem do ściany - i biblioteka gotowa. Tam widnieje Anatomia, Fizjologia Drapera, Małecki, 14 tomów dzienników, zresztą kajeta z moimi „dziełami”, czapka studencka i jedna szelka.

Tak więc - w rok po opuszczeniu gimnazjum i wyjeździe $z$ Kielc - notesy diariusza są z Żeromskim w Warszawie. I posiada on je (jak się okaże - nie wszystkie) tak długo, jak długo dziennik prowadzi, to jest aż do roku 1892. Potem jednak jego sytuacja życiowa się zmienia. We wrześniu 1892 pisarz bierze ślub z Oktawią Rodkiewiczowa, w październiku tego roku zamieszkuje z nią i jej córką z pierwszego małżeństwa w Rapperswilu w Szwajcarii, gdzie podejmuje pracę w Muzeum Narodowym Polskim; opuszcza kraj na co najmniej kilka lat, ale $z$ pewnością nie na zawsze, jednak zabiera $z$ sobą dzienniki. Gdy się czyta niektóre jego utwory powstałe wówczas w Szwajcarii, takie jak Mogiła, W sidłach niedoli czy fragmenty Syzyfowych prac, widać wyraźnie, że w czasie pisania właśnie dziennikami posiłkował się jako źródłem wspomagającym budowanie fabuły, kreowanie postaci, przedstawianie miejsc i ludzi. Potem, kiedy po powrocie ze Szwajcarii w roku 1896 Żeromski osiada na stałe w Nałęczowie i Warszawie, dzienniki są niewątpliwie znowu przy nim. W końcu 1908 roku autor Popiołów zostaje aresztowany, a na-

$6 \quad$ S. Że r o m s ki, Listy 1884-1892. Oprac. Z. J. Ad a m c zy k. Warszawa 2001, s. 94. Pisma zebrane. T. 34. Listy Żeromskiego - w sześciu tomach - wydane zostały w ramach jego Pism zebranych pod redakcją Z. Golińs kiego.

7 Ibidem, s. 197-198.

8 Ibidem, s. 310. 
stępnie najprawdopodobniej wydalony z granic państwa rosyjskiego; wyjeżdża do Galicji ze świadomością, że do Warszawy i Królestwa nie będzie mógł wrócić - zabiera więc, najpierw do Krakowa, a potem do Zakopanego, całe swoje literackie archiwum, w tym dzienniki. Nie na długo. Jesienią 1909 na parę lat wyprowadza się z żoną i synem do Paryża. Tym razem wiadomo, jak zadbał o całość i bezpieczeństwo swojego archiwum. Przed wyjazdem zapakował je w kilka koszy i zdeponował na strychu zakopiańskiej willi dra Edmunda Brzezińskiego. Tułaczka tego wielkiego zbioru rękopisów (niemała jego część stanowiły otrzymywane przez Żeromskiego i pieczołowicie przechowywane listy) trwała aż do roku 1920, kiedy wreszcie znalazł on bezpieczne i stabilne miejsce w willi Świt w Konstancinie. $\mathrm{W}$ trakcie ciągnących się prawie 40 lat wędrówek jakieś notesy z dziennikowymi zapisami mogły się gdzieś zagubić lub ulec zniszczeniu.

O tym, że jakiś tomik zawieruszył się w Kielcach i jest ulubioną lekturą tutejszych ciekawskich, Żeromski dowiedział się pod koniec 1912 roku od swojej ciotecznej siostry, Marii z Saskich Albrechtowej, która w dniu 26 XII 1912 poinformowała go:

Kochany Stefanie!

Donoszę Ci, że Twój dzienniczek pisany w czasach uczniowskich kursuje po Kielcach i jest tematem różnych komentarzy. Ponieważ w dzienniczku tym zawarte są nasze sprawy rodzinne, list i wierszyki Ludwiki Zlasnowskiej, warto by go z obiegu wycofać, wobec czego zwracam się do Ciebie z prośbą, abyś mi przysłał upoważnienie do odebrania tego dzienniczka $\mathrm{z}$ rąk, w których się w danym momencie znajdzie. Po odebraniu dziennika nie omieszkam Ci go natychmiast odesłać. W nadziei, że list niniejszy da mi zarazem sposobność dowiedzenia się czegoś o Tobie i Adasiu, przesyłam Ci serdeczne uściśnienia

Maria Albrechtowa ${ }^{9}$.

W tym samym mniej więcej okresie podobny list wysłał do Żeromskiego inny jego krewny, cioteczny siostrzeniec, Stanisław Piołun-Noyszewski, wówczas początkujący literat, później dziennikarz, krytyk literacki, autor powieści i nowel, a także pierwszej obszernej - zaśmieconej jednak zmyśleniami i bałamuctwami - książki o młodości Żeromskiego ${ }^{10}$; ten list Noyszewskiego nie zachował się, nie da się więc ustalić, jakie zawierał informacje o „kursującym” po Kielcach tomiku. Wiadomo natomiast, iż 30 XII 1912 Żeromski napisał do Zofii Kozierkiewiczowej, w której rękach tomik wtedy się znajdował. List ten był kilkakrotnie publikowany, wypada jednak i tutaj go przypomnieć:

Wielmożna Pani!

Od osób przyjaznych mi powziąłem wiadomość, że w posiadaniu Wielmożnej Pani znajduje się mój notatnik z r. 1882, kiedy byłem uczniem gimnazjum kieleckiego. Nie wiem, jakim sposobem to pismo znalazło się w ręku Wielmożnej Pani, a nieznajomością mego adresu tłomaczę sobie fakt, iż Wielmożna Pani nie raczyła mi go zwrócić. Pragnąc Jej to ułatwić, uprosiłem moją krewną, Panią Marię Albrechtową, oraz mego siostrzeńca, p. Stanisława Noyszewskiego, ażeby raczyli udać się do Wielmożnej Pani i prosić Ją o wydanie im wymienionej książeczki, a również wszelkich moich rękopisów czy listów, które by w Jej posiadaniu zaleźć się mogły podobnie jak dziennik, aczkolwiek nie miałem nigdy przy-

9 Autograf listu znajduje się w Bibl. Narodowej, rkps 17218. T. 1. Zob. też S. Żerom ski, Listy 1905-1912. Oprac. Z. J. Ad a m c zy k. Warszawa 2006, s. 433-438. Pisma zebrane. T. 37.

10 S. Pi oł u n - N o y s z e w s ki, Stefan Żeromski. Dom, dzieciństwo i młodość. Warszawa 1928 (właśc. 1927). 
jemności znać osobiście Wielmożnej Pani. W nadziei, że Wielmożna Pani nie odmówi zwrócenia mi mej własności najbardziej godnej tego określenia, gdyż zawierającej osobiste, dziecięce niemal zwierzenia i notatki, dla samego siebie tylko pisane i nigdy nieprzeznaczone do czyjegokolwiek posiadania, a tym mniej do publikacji w jakiejkolwiek formie, upraszam o wydanie w ręce Oddawców niniejszego pisma zarówno dziennika, jak innych papierów pisanych moją ręka, o ile się znajdują w posiadaniu Wielmożnej Pani ${ }^{11}$.

\section{Tego samego dnia napisał i do Piołun-Noyszewskiego:}

Najserdeczniej dziękuję Ci, Drogi Przyjacielu, za łaskawe ostrzeżenie co do owego dziennika z lat dawnych i nigdy nie zapomnę tej przyjacielskiej usługi, jaką mi wyświadczysz, odbierając owo pismo z rąk iście kieleckich. [...] W głowę zachodziłem, skąd ten dziennik mógł się znaleźć w rękach zupełnie mi nieznajomej osoby. Nazwisko jednak wskazuje na to, że moja macocha w czasie pobytu w Kielcach znała niejakiego pana [...], urzędnika z guberni czy pałaty. Myślę, że to od niego pochodzić musi to wątpliwej wartości dziedziczenie i niemniej małej wartości spadek. Być może, że tam być mogą jakie listy pisane do mnie albo jakieś młodociane grzechy literackie. Rad bym to wycofać i zniszczyć albo przynajmniej odebrać $\mathrm{z}$ rąk tak mało dyskretnych ${ }^{12}$.

Zofia Kozierkiewiczowa spełniła jego prośbę. I to wszystko. Wokół tej sprawy narosło jednak tyle nieporozumień, iż trzeba się przy niej zatrzymać na dłużej.

Gdy w roku 1927 Piołun-Noyszewski przygotowywał wspominaną książkę biograficzną, pragnąc, być może, wyeksponować własną rolę w całej tej historii i swoje zasługi dla wielkiego kuzyna, rozmnożył liczbę zaginionych notatników. Napisał:

dziennik swój [...] Żeromski [...] zgubił a raczej zapomniał na jednym ze swych pied-à-terre w Kielcach. Przez lat dziesiątki oparł się on zniszczeniu, aż wreszcie wydobyto go z zapomnienia w sposób niebaczny i lekkomyślny. Ku najwyższemu zdumieniu dowiedziałem się, że na pewnej pensji żeńskiej dziewczęta, z zapałem godnym lepszej sprawy, rozczytują się w jakimś pamiętniku Stefana Żeromskiego. Po dotarciu do źródła wersji przekonałem się, że, istotnie, najtajniejsze, sobie tylko zwierzane myśli autora Popiołów poniewierają się w sposób najbardziej nieodpowiedni, narażone na żarty płochych dziewcząt, dla których, nawiasem mówiąc, były lekturą fatalną. Wyegzekwowanie rękopisów nie obyło się bez trudności. Radość pisarza z odnalezienia dziennika była ogromna. Po prostu nie chciał na razie wierzyć, że ukochane zeszyty jeszcze istnieją i że je niebawem otrzyma. [...] Pamiętnika, po odebraniu z Kielc, nie zniszczył. Postąpił słusznie, są w nim bowiem bardzo cenne przyczynki do jego życia i twórczości. O ile wiadomo jednak, wyrwał zeń niektóre karty, których nie chciał nikomu przekazywać. A kart takich było tam, zdaje się, wiele ${ }^{13}$.

Ta opowieść Noyszewskiego stała się źródłem utrzymującej się do dziś legendy o zaginięciu - na dziesięciolecia - wielu, może nawet wszystkich tomików. Uwierzyli w nią liczni badacze, wśród nich Jerzy Kądziela, który w roku 1963 napisał:

[swoje dzienniki Żeromski] zostawił [...] w Kielcach, w domu macochy, Antoniny z Zeitheimów, która szczegół nieobojętny - prowadziła stancję uczniowską. Odtąd zniknęły z oczu autora na lat dwadzieścia z okładem. Co się z nimi wówczas działo, niepodobna dociec. Po latach wypłynęły z zapomnienia na pewnej pensji żeńskiej w Kielcach, gdzie stały się lekturą dorastających dziewcząt. Rzecz działa się

Że ro m s ki, Listy 1905-1912, s. 435-436. List ten publikowany był też wcześniej przez J. Kąd zi e lę (O „Dziennikach” Stefana Żeromskiego. „Twórczość” 1963, nr 2 〈bez nazwiska adresatki〉; przedmowa w: S. Żeromski, Dzienniki. T. 1. Warszawa 1963, s. 6. Dzieła 〈bez nazwiska adresatki〉) oraz przez K. Za p ał ow a (Listy Stefana Żeromskiego w zbiorach kieleckiego muzeum. „Rocznik Muzeum Narodowego w Kielcach” 1984, s. 279). 
jeszcze przed pierwszą wojną światową, kiedy większość osób opisanych w Dziennikach żyła. Można sobie wyobrazić, jak niezdrowe sensacje budziła taka lektura wśród młodzieży. Pisarz dowiedział się o tym w roku 1912 za pośrednictwem swego siostrzeńca, Stanisława Noyszewskiego. Postanowił odebrać stare zeszyty „Z rąk tak mało dyskretnych”, „rąk iście kieleckich”, jak pół gniewnie, pół żartem napisał do Noyszewskiego dnia 30 grudnia 1912 r. ${ }^{14}$

Informacje te rozwinęła Kazimiera Zapałowa, kierowniczka Muzeum Lat Szkolnych Stefana Żeromskiego w Kielcach, do którego ostatecznie trafił autograf listu Żeromskiego do Kozierkiewiczowej. Zapałowa zanotowała:

Liczne zmiany stancji, brak stałego zamieszkania, brak rodzinnego domu [...], gdzie przechowuje się wszystkie drogie przedmioty, sprawiły, że zarówno szkolne kajety, młodzieńcze zapiski Stefana Żeromskiego rozpierzchły się gdzieś, poginęly na strychach stancyjnych kamienic, niektóre zaciekawiły obcych, stały się tematem plotek, komentarzy, domysłów. Taki los spotkał pamiętniki pisarza, które, pozostawione w mieszkaniu macochy, Antoniny Zeitheim-Żeromskiej [...], znalazły się po latach w domu mieszczańskiej rodziny Kozierkiewiczów, których córka Wanda, przeglądając książki i domowe archiwalia, zobaczyła w ojcowskiej bibliotece jakieś interesujące zapiski sprzed lat i, przeczytawszy, przyniosła tę pasjonującą lekturę swym koleżankom z pensji Marii Krzyżanowskiej. W szkole, a później w mieście zawrzało. Wszak żyli tu statecznie i świątobliwie ci, o których Żeromski w bardzo osobisty sposób pisał, a i on sam nie był już nieznanym gimnazjalistą, na którego dzienniki nikt nie zwróciłby uwagi, lecz wybitnym literatem, którego dzieła wywoływały głośne polemiki ${ }^{15}$.

Zapałowa korzystała z informacji córki Zofii, Wandy Kozierkiewicz-Hamburgowej, która w roku 1912 ów rękopis dziennika znalazła, a po latach przekazała do kieleckiego Muzeum autograf listu Żeromskiego do jej matki.

Z czasem Kądziela zmienił zdanie na temat losów autografów dziennika. Dostrzegając znaczne podobieństwa między powstałymi w okresie pracy twórcy w Rapperswilu (1892-1896) nowelami Mogiła i W sidłach niedoli a wcześniejszymi zapisami w dziennikach, przyszedł do wniosku, iż Żeromski zabrał swój dziennik, gdy wyjeżdżał do Szwajcarii - i dopiero po powrocie do kraju zostawił go u macochy w Kielcach. We wstępie do wydanego w 1980 roku wyboru z Dzienników przedstawił to tak:

Wiele przemawia za tym, że [Żeromski] często je [tj. dzienniki] przeglądał, np. pisząc latem $1892 \mathrm{r}$. opowiadanie Oko za oko, i że miał je ze sobą w Rapperswilu, gdzie powstała Mogiła i $W$ sidłach niedoli. W każdym $\mathrm{z}$ wymienionych utworów znajdują się bowiem całe partie sparafrazowane lub wprost przepisane z Dzienników. Dopiero później, przed kolejnym wyjazdem za granicę, zostawił je pisarz w Kielcach, w domu macochy, Antoniny z Zeitheimów Żeromskiej, która - szczegół nieobojętny - prowadziła stancję uczniowską. Odtąd zniknęły z oczu autora na lat kilkanaście. Co się wówczas z nimi działo, niepodobna dociec. Po latach wypłynęły z zapomnienia na pewnej pensji żeńskiej w Kielcach, gdzie stały się lektura dorastających dziewczat ${ }^{16}$.

Temu wyjaśnieniu Kądzieli dał wiarę - chociaż nie całkiem - Paweł Rodak. Zacytowawszy przytoczony tu fragment wstępu, napisał:

14 Ką d zi e la, przedmowa, s. 5. H. M ort k ow i c z-O l c z a k ow a w swej książce O Stefanie Żeromskim. Ze wspomnień i dokumentów (Warszawa 1964, s. 66) napisała nawet, że dzienniki, „zostawione u macochy i zagubione, poniewierały się dłuższy czas w Kielcach, przechodziły z rąk do rąk. Nikt ich nie chronił od niepowołanych czytelników, a nawet były podobno ulubioną lekturą kieleckich pensjonarek".

15 Za pałowa, op. cit., s. 277-278.

16 Ką dziela, wstęp w: Że ro m ski, Dzienniki. (Wybór), s. VII. 
Dzisiaj ten powszechnie przyjęty sąd wielkiego znawcy dziennika Żeromskiego, autora jego krytycznej edycji, wymaga pewnej korekty. Otóż trudno sobie wyobrazić, aby pisarz zostawił w Kielcach wszystkie dwadzieścia kilka tomików dziennika, skoro stanowiły dla niego wielką osobistą wartość (Żeromski niezmiernie cieszył się $\mathrm{z}$ ich odzyskania) oraz mogłyby ciagle być mu użyteczne w dalszej twórczości. Bardziej prawdopodobne niż to, że pisarz przekazał cały dziennik w ręce macochy, jest zatem jego przypadkowe, a może i nieświadome pozostawienie w Kielcach. Dotyczyłoby ono przy tym nie całości dziennika, ale tylko pierwszego lub kilku pierwszych jego zeszytów, które, być może, Żeromski zabrał, jadąc po latach do Kielc, by, czytając je, odtworzyć okres szkolnej młodości, lub które zostawił tam wcześniej. Jak wiadomo, przypomniała mu o tej zgubie Maria Albrechtowa w liście z 26 grudnia 1912 roku $^{17}$.

To zmodyfikowane twierdzenie Kądzieli budzi zdumienie, nie jest bowiem poparte żadnymi dokładniejszymi informacjami, kiedy mianowicie, przed jaką następną podróżą - i dlaczego - miałby Żeromski swe dzienniki pozostawić w Kielcach u macochy. Od powrotu ze Szwajcarii latem 1896 do końca 1908 roku mieszkał w Warszawie, rodzina jego żony posiadała w Nałęczowie willę Oktawia, on sam w roku 1905 wybudował w pobliżu tej willi letni dom („chatę”), jeśli więc wyjeżdżał na dłużej, a przecież wyjeżdżał, całe swoje archiwum pisarskie mógł spokojnie pozostawiać pod opieka najbliższych. Dlaczego akurat dzienniki miałby wywozić do Kielc?

I jest jeszcze szkopuł drugi: nikt chyba nie wie, do kiedy Antonina z Zeitheimów Żeromska mieszkała w Kielcach.

Tutaj się urodziła. Jej dziadek, Antoni Zeitheim, przybyły do Kielc z Galicji przed rokiem 1811, był geometra - zatrudnionym najpierw w Kielcach (w dobrach narodowych klucza kieleckiego), potem pracującym w rozmaitych dworach szlacheckich: w Denkowie, Chełmcach, Kozienicach, pewnie gdzieś jeszcze, a wreszcie osiadłym na dobre w Kielcach, gdzie od roku 1819 zatrudniony był we władzach rządowego górnictwa i hutnictwa Królestwa Polskiego, dokładniej zaś - w Komisji Rządowej Spraw Wewnętrznych i Policji jako geometra dóbr górniczych. Wkrótce potem, w latach 1823-1825, wybudował przy swym domu publiczną łaźnię, która prowadził aż do śmierci w styczniu 1842. Jego najstarszy syn, Józef Zeitheim, urodzony około 1812 roku, był w Kielcach urzędnikiem w Kontroli Skarbowej przy Sądach Guberni Krakowskiej, potem zarządzał także odziedziczoną po ojcu łaźnią; miał liczne potomstwo; Antonina była najstarsza jego córką. Nie dysponujemy danymi, gdzie się kształciła, wiadomo, że prowadziła stancję dla uczniów kieleckiego gimnazjum - najpierw, w latach siedemdziesiątych - w domu ojca, przy którym usytuowana była wspominana łaźnia, potem ponownie, po śmierci Wincentego Żeromskiego, od września 1885 w wynajętym lokalu. W Kielcach mieszkała też jej młodsza siostra Feliksa, żona urzędnika izby skarbowej, Edmunda Kłodnickiego. Z dziennika Żeromskiego wynika, że Antonina Żeromska utrzymywała stancję jeszcze w roku 1890, chociaż interes zapewne nie kwitł wtedy świetnie. Nadzór nad stancjami sprawował inspektor z gimnazjum. Pod datą 9 IX 1890 Żeromski zapisał w dzienniku: „Drżę cały, gdy myślę, jakie przykrości znosi od inspektora moja macocha. Zrujnował ją umyślnie”.

Antonina mieszkała w Kielcach jeszcze w styczniu 1892. W drodze z Warszawy

17 P. Rodak, Między zapisem a literatura. Dziennik polskiego pisarza $w$ XX wieku (Żeromski, Natkowska, Dąrowska, Gombrowicz, Herling-Grudziński). Warszawa 2011, s. 132. 
do Krakowa Żeromski odwiedził ją 10 I 1892; z napisanego następnego dnia jego listu do Oktawii Rodkiewiczowej nie wynika, czy macocha nadal prowadziła stancję. W jednym $z$ kolejnych listów do Oktawii, datowanym 12 II 1892, a więc 8 miesięcy przed wyjazdem do Rapperswilu, swoje stosunki z macochą scharakteryzował następująco: „Nigdy ona nie wie, co robię ze soba, gdzie jestem, czy jestem żonaty czy kawaler, czy mam jakieś utrzymanie, czy nie" ${ }^{18}$. W roku 1895 zmarła Feliksa Kłodnicka - ostatnia pozostająca w Kielcach osoba $\mathrm{z}$ rodziny Zeitheimów. Inna siostra Antoniny, najbliższa jej uczuciowo Helena, mieszkała wówczas na warszawskiej Pradze; jej mąż, Leon Radziszewski, zatrudniony w tym okresie jako „agent” kolei warszawsko-terespolskiej, wkrótce potem otrzymał stanowisko naczelnika stacji w Mławie, a mówiąc dokładniej: w Wólce Mławskiej; gdy w roku 1904 zmarł, pracę w kasie biletowej podjęła wdowa po nim.

Nie wiadomo, kiedy dokładnie, ale na pewno przed rokiem 1914, zamieszkała w Wólce także Antonina. Po wybuchu pierwszej wojny światowej, prawdopodobnie w związku z ewakuacją w głąb Rosji personelu kolejowego, a może $z$ jakichś innych powodów, Helena i Antonina trafiły do Moskwy, mieszkały jednak oddzielnie. Wydany tam „Kalendarz Polski. Rocznik wychodźstwa polskiego w Rosji na rok 1916” zawiera m.in. Księgę adresowa Polaków $w$ Rosji, w której znalazły się także: „Radwan-Radziszewska Helena z Mławy, Moskwa, III Samotiecznyj nr 13 m. 21" oraz „Żeromska Antonina z Mławy, Moskwa, Wasilewskaja nr $11 \mathrm{~m}$. 24”. Po powrocie do kraju, aż do śmierci w roku 1920, macocha Żeromskiego mieszkała w Mławie. Niewiele - jak widać - o jej życiu wiadomo, nie potrafimy ustalić również: kiedy z Kielc wyjechała.

Można zatem powątpiewać nie tylko w kwestii, po co Żeromski miałby wywozić dzienniki do Kielc i zostawiać je u macochy, ale także - kiedy miałby to uczynić, skoro nie jest nawet pewne, czy w chwili powrotu Żeromskich z Rapperswilu Antonina jeszcze w Kielcach mieszkała.

Utrzymujące się od lat twierdzenie o pozostawieniu przez Żeromskiego w Kielcach kilku - a może nawet wszystkich - tomików dziennika trzeba raz na zawsze odrzucić. Wymowa faktów jest następująca:

Maria Albrechtowa, która w grudniu 1912 miała w rękach „zgubę” Żeromskiego, donosiła mu o kursującym po Kielcach „dzienniczku” (a nie o „dzienniczkach”), w którym „zawarte są nasze sprawy rodzinne, list i wierszyki Ludwiki Zlasnowskiej”; pisała więc o pierwszym, najwcześniejszym tomiku dziennika, obejmującym notatki $z$ okresu od 19 V do 15 XII 1882. To w tym tomiku, pod datą 8 IX 1882, Ludwika, wówczas Borkowska, a w rok później już Zlasnowska, wpisała czterowiersz:

Tu, gdzie te kartki łączą swe ramiona
I obraz stawią niezłomnej przyjaźni,
Myśl moja w kraje marzeń zaniesiona
Zbierała słodycz z kwiatków wyobraźni.

To w tym - i tylko w tym - tomiku Ludwika jest obiektem westchnień niespełna osiemnastoletniego Żeromskiego. Także on sam dużo później, gdy w roku 1912 
pisał do Kozierkiewiczowej, prosił o zwrot nie „notatników”, lecz „notatnika z r. 1882". W listach z roku 1912 mowa jest, jak widać, o zaginionym jednym (najwcześniejszym) tomiku.

Na stancji u swojej przyszłej macochy Żeromski mieszkał po raz pierwszy, kiedy uczęszczał do klasy drugiej, tzn. albo w roku szkolnym 1877/78, albo w 1878/79 (klasę drugą repetował), ale wówczas tomiku nie mógł tam zostawić, bo dziennika jeszcze nie prowadził. Ponownie przebywał na stancji u macochy, czy nawet współprowadził tę stancję, w roku szkolnym 1885/86, gdy był uczniem klasy ósmej, maturalnej, tj. gdy po śmierci Wincentego Żeromskiego wdowa po nim, Antonina Żeromska powtórnie zamieszkała w Kielcach (tzn. powróciła tutaj z Ciekot) i na nowo założyła stancję. To wtedy zapewne, gdy na początku jesieni 1886 Żeromski przenosił się $z$ Kielc do Warszawy, ten najwcześniejszy tomik dziennika pozostawił w mieszkaniu macochy. Zofia Kozierkiewiczowa była (od roku 1905) wdowa po Bolesławie Kozierkiewiczu, buchalterze w rządowej izbie skarbowej („kazionnoj pałacie”) w Kielcach, gdzie przez lata pracował także szwagier Antoniny, Edmund Kłodnicki. Do rodziny Kozierkiewiczów tomik mógł trafić kanałem rodzinno-towarzyskim. Tylko jeden tomik: najwcześniejszy - z roku 1882. Wszystkie późniejsze Żeromski zabrał do Warszawy i potem przez wiele lat się $\mathrm{z}$ nimi nie rozstawał. W dniu 5 VI 1887, gdy w dzienniku opisywał swój ubogi studencki pokój, wyjawił przecież, że posiada „14 tomów dzienników”.

Dziennik, jak już było powiedziane, stanowił dla Żeromskiego zbiór materiałów fabularnych: sylwetek, zdarzeń, opisów - chętnie wykorzystywanych przezeń zwłaszcza w początkach twórczości. Pewne fragmenty dziennika, zmienione, rzecz jasna, i udoskonalone, niemal dosłownie zostały wcielone do niektórych wczesnych utworów. Opowiadanie znane ostatecznie pod tytułem $Z$ dziennika (drukowane w grudniu 1889 w „Głosie” pod tytułem Pod pierzyna) jest przeróbką zapisanej w dzienniku pod datą 28 I 1889 obszernej relacji z podróży z Oleśnicy do Kotuszowa, odbywanej przez Żeromskiego w towarzystwie młodych panów Zaborowskich. W czasie tej podróży, w trakcie przejazdu przez zamarznięta rzekę, lód załamuje się pod bryka, podróżni zostają wyniesieni $z$ lodowatej wody przez chłopów z okolicznych chałup, potem w tychże chałupach suszą się i grzeją pod wiejskimi pierzynami, a następnie ruszają w dalsza drogę. Gdy ma się przed oczami zapis dziennikowy i wydrukowany tekst opowiadania, widać, jak młody autor przenosił do niego $z$ diariusza opisy, zdarzenia, dialogi.

Podobne analogie i zależności można zobaczyć w Zapomnieniu (druk w sierpniu 1891), gdzie opis świtu na samym początku opowiadania jest przeróbką opisu wschodu słońca nad stawem w Brodach w pobliżu Oleśnicy (w dziennikach pod data 24 V 1889) - czy w obszernym utworze $W$ sidłach niewoli (druk w roku 1895), w którym perypetie bohatera przymierającego głodem w Warszawie, a potem korzystającego $z$ uroków dostatniego życia na wsi wzorowane są na doświadczeniach Żeromskiego zrelacjonowanych w dzienniku - najpierw w maju i czerwcu 1887, gdy cierpiał biedę w Warszawie, a następnie (latem 1888), gdy na zaproszenie Józefa Saskiego przez kilka tygodni gościł w Kurozwękach. Pisał o tym także Kądziela ${ }^{19}$. 
Gdyby tomiki, o których tutaj mowa, wróciły do Żeromskiego dopiero w roku 1912 , opowiadania $Z$ dziennika, Zapomnienie i $W$ sidłach niedoli oraz całe rozdziały $S y$ zyfowych prac albo by nie powstały, albo miałyby zupełnie inny kształt.

Czy - tak chętnie i tak często posiłkując się dziennikami w trakcie pracy twórczej - mógł Żeromski nie zorientować się, iż jeden tomik zaginął? Z jego reakcji na wiadomości od Albrechtowej i od Noyszewskiego, a także $z$ jego listu do Kozierkiewiczowej zdaje się wynikać, że mógł tego nie zauważyć.

I dałoby się to nawet zrozumieć. Gdy Żeromski sięgał do dzienników, by posłużyć się nimi jako pewnego rodzaju tworzywem literackim, wykorzystywał tomiki późniejsze, kiedy swe diarystyczne notatki traktował również jako swoiste ćwiczenia pisarskie; notatnik z roku 1882, wypełniony głównie lakonicznymi, kilkuzdaniowymi informacjami o zdarzeniach szkolnych i koleżeńskich, do takich celów nie był potrzebny. Autor mógł o nim nie pamiętać.

Wszystko to zdaje się świadczyć, że przed rokiem 1912 pisarz stracił z oczu tylko pierwszy, najwcześniejszy tomik.

Co nie oznacza, że za jego życia żaden tomik nie mógł ulec zatraceniu.

Nie da się wykluczyć, że jakieś tomiki mogły zostać zagubione lub zniszczone jeszcze przed tym, nim cały zbiór trafił pod koniec 1920 roku do bezpiecznego azylu w willi Świt, nie udało się bowiem ustalić, ile tomików dziennika przyjechało wtedy do Konstancina. Dom - wreszcie własny - dawał dziennikom schronienie, ale nie ma pewności, że wszystkie przywiezione wówczas tomiki zachowały się w Konstancinie aż do śmierci Żeromskiego w listopadzie 1925. Jakiś tomik bądź jakieś tomiki autor mógł komuś pożyczyć - i ich nie odzyskać. Istnieją podstawy do takich przypuszczeń.

W wielkim zbiorze korespondencji Żeromskiego, przechowywanym obecnie w Bibliotece Narodowej, znajdują się - wśród kilku tysięcy innych - trzy listy studenta Uniwersytetu Jagiellońskiego, Adama Dobrowolskiego z Sosnowca, który w roku $1925 \mathrm{w}$ ramach seminarium prof. Ignacego Chrzanowskiego przygotowywał pracę na temat subiektywizmu w utworach powieściowych Żeromskiego i w związku z tym - w pierwszym z listów, datowanym 22 IV 1925 - zwrócił się do autora Popiołów, aby „raczył łaskawie udzielić” mu „swoich pamiętników lub wskazówek”, co pozwoliłoby mu rozprawkę napisać; z następnych zaś wynika, iż 11 V Żeromski odpowiedział Dobrowolskiemu i obiecał wypożyczyć coś z pamiętników, ale ostatecznie chyba tego nie uczynił ${ }^{20}$. Zupełnej pewności w tej kwestii mieć nie można ${ }^{21}$, jednak nawet jeśli niczego Dobrowolskiemu nie wysłał, to zdumiewa już sama

Zob. Bibl. Narodowa, rkps 17218. T. 8. Pierwszy z zachowanych listów zawiera prośbę; w drugim, datowanym 25 VI 1925, Dobrowolski napisał: „Wielce Dostojny Panie! List Wielce Sz. P. z dnia 11 maja br., obiecujący mi przesłanie materiału do mojej pracy, sprawił mi wielką i niekłamaną radość. Zasmuciła mię natomiast wielce choroba Wielce Sz. P. Nie odpisałem od razu, gdyż sądziłem, że wkrótce będzie mi mógł W. Sz. P. przesłać obiecany pamiętnik”. Dalej student podawał swój wakacyjny adres domowy (w Sosnowcu) i prosił o nadesłanie dziennika pod tamten adres. Wyrażał też gotowość przyjechania po materiały do Warszawy.

21 W trzecim liście, datowanym 16 IX 1925, Dobrowolski przypominał swoją sprawę i ponaglał: „Ufam, że W. Sz. Pan, pomny na obietnicę, zechce łaskawie przyjść mi z pomocą i udzieli mi części Swego pamiętnika”. Żeromski chyba raczej prośby nie spełnił; gdyby spełnił, Dobrowolski bez wątpienia 
obietnica - obietnica pożyczenia jakiegoś tomiku bądź jakichś tomików dziennika komuś, kogo zupełnie nie znał. Nie wiadomo także, czy podobnych próśb nie otrzymywał więcej - i czy którejś nie uległ.

Krótko przed śmiercią, 5 VI 1925, Żeromski spisał testament, w którym rozporządził także swoim pisarskim archiwum:

Zbiór książek moich, znajdujących się w willi Świt w Konstancinie, i zbiór korespondencji, alfabetycznie i rzeczowo ułożony, zbiór recenzji, pamiętników i książek z dedykacjami zapisuję Polskiemu Klubowi Literackiemu z tym jednak zastrzeżeniem, ażeby ten cały zbiór nie był dzielony i mógł stanowić całość jak obecnie ${ }^{22}$.

„Pamiętniki”, czyli dzienniki, przeznaczył zatem Żeromski dla Polskiego Klubu Literackiego, tj. dla polskiego oddziału Pen Clubu. Ten zapis testamentowy nie został zrealizowany.

Założony przez Żeromskiego w 1925 roku polski Pen Club początkowo korzystał jedynie ze skromniutkiego pomieszczenia w Zamku Królewskim w Warszawie, nie miał więc warunków, by darowiznę przyjąć. Dopiero po kilku latach uzyskał większy lokal przy ul. Pierackiego (dziś Foksal) i wówczas, w początkach 1936 roku, archiwum Żeromskiego trafiło do Pen Clubu; trafiło jednak w postaci uszczuplonej. „Ze zbioru papierów pozostałych po Stefanie Żeromskim” Anna i Monika Żeromskie wyłączyły dokumenty mogące mieć dla nich wartość majątkową, uznały je za „nieobjęte legatem" i zatrzymały dla siebie. Były to głównie umowy i korespondencja z polskimi i zagranicznymi firmami wydawniczymi oraz przedsiębiorstwami kinematograficznymi ${ }^{23}$. Nie oddały także do Pen Clubu dzienników, które zostały w Konstancinie. Żeromski w testamencie o żadnych „wyłączeniach” nie wspominał, miał tylko jeden warunek: by przekazane Pen Clubowi jego pisarskie archiwum nie było dzielone. I akurat w tym punkcie jego woli spadkobierczynie nie uszanowały.

Przez wiele następnych lat tomiki dzienników znajdowały się u pań Żeromskich. Głośno stało się o nich w roku 1932 - w związku z procesem sądowym, wytoczonym przez Zenona Przesmyckiego-Miriama dziennikarzom publicznie oskarżającym go m.in. o przywłaszczenie sobie rękopisów Żeromskiego. W tamtym czasie w kilku periodykach pojawiły się artykuły wytykające Miriamowi, iż przez lata przechowuje w domu zebrane przez siebie autografy Cypriana Norwida i Józefa Marii Hoene-Wrońskiego, które miał ogłosić drukiem i których jednak nie publikuje; do tych zarzutów dziennikarz z tygodnika „Jutro Pracy” Jerzy Horzelski dołożył oskarżenie:

W niesłychanej chciwości gromadzenia i przechowywania materiałów literackich Przesmycki wszedł w posiadanie rękopisów Żeromskiego przekazanych testamentem Penklubowi. Ówczesny prezes Penklubu uważał za bezpieczne miejsce przechowania jedynie półki własnej biblioteki. [...] Wśród rękopisów Żeromskiego utopionych w bibliotece Przesmyckiego znajduje się maszynopis i rękopis wykończonej

podziękowałby za przesyłkę, a odpowiedzi takiej w zbiorze listów do Żeromskiego nie ma. To jednak tylko domysł, a nie pewność.

22 Cyt. z: Stefan Żeromski. Kalendarz życia i twórczości. Wyd. 2. Oprac. S. Eile, S. Kasztelowi i z. Kraków 1975, s. 612. Oryginał testamentu nie jest znany.

23 Kopia listu A. i M. Że ro m s ki ch do Zarządu Polskiego Klubu Literackiego, z 1 III 1936, w posiadaniu autora artykułu. Te wyłączone przez panie Żeromskie dokumenty uległy zagładzie w niejasnych okolicznościach 
prawie (podobno) powieści pt. Wiosna, a stanowiącej niejako drugą część Przedwiośnia. Dalej jest tam bezcenny wręcz dokument dla biografów Żeromskiego, a mianowicie obszerny, a własnoręcznie pisany pamiętnik. W nim Żeromski spowiadał się ze swych nadziei, bólów, trudności, w nim zawarł wszystko to, czego przedwczesna śmierć nie pozwoliła rozwinąć w ostateczne kształty twórczości artystycznej, w nim znaczył poszczególne etapy swej działalności literackiej. Poza tym wśród szeregu nieznanych bliżej dokumentów znajduje się tam ogromny, pieczołowicie składany przez śp. Oktawię Żeromską zbiór listów nadchodzących do Żeromskiego od zarania jego twórczości aż do chwil ostatnich i to wraz z kopiami odpowiedzi ${ }^{24}$.

Oskarżenie to przedrukował Jerzy Braun w artykule Problemat Miriama w numerze 5 dwutygodnika „Zet” z 1 VI 1932.

Podane przez Horzelskiego informacje o powieści Wiosna, dziennikach i zbiorze listów do Żeromskiego, rzekomo gromadzonych przez Oktawię Żeromską, są zupełnie fantastyczne, a zarzuty - niedorzeczne. Skłoniły one Przesmyckiego do wytoczenia Horzelskiemu i Braunowi procesu o zniesławienie; w sądzie zeznawały w tej sprawie powołane na świadków Janina Mortkowiczowa i Anna Żeromska; dzięki tej dziennikarskiej aferze i szeroko relacjonowanemu w prasie procesowi sądowemu opinia publiczna dowiedziała się zarówno o tym, iż Żeromski prowadził dziennik, jak i o tym, jak jest on traktowany przez spadkobierczynie autora. Sprawozdawca sądowy warszawskiego „Kuriera Polskiego” tak zrelacjonował zeznania świadków:

Pamiętnik ten - jak zaznacza p. Mortkowiczowa - posiada do dziś dnia p. Żeromska; nie będzie on jednak nigdy wydrukowany, ponieważ zawiera zwierzenia wielkiego pisarza. Rękopisy nowej powieści, stanowiącej dalszy ciąg Przedwiośnia, są raczej szkicem, który nigdy nie znajdował się w posiadaniu p. Przesmyckiego.

Według słów p. Żeromskiej stosunki jej śp. męża z p. Miriamem były b. zażyłe.

Przew[odniczący]: Czy mąż pani pozostawił jakie rękopisy?

Św[iadek]: Zaledwie kilkanaście stron notatek, które wydano w Elegiach ${ }^{25}$.

Żeromski, powtórzmy, swe dzienniki - bez żadnych zastrzeżeń w sprawie ewentualnej publikacji - zapisał w testamencie polskiemu Pen Clubowi, natomiast Anna Żeromska już w roku 1932 przyznaje sobie prawo decydowania, czy będą one kiedykolwiek publikowane, potem zaś, w roku 1936, gdy - realizując testamentowy zapis - przekazuje Pen Clubowi kilkaset książek, zbiór recenzji i większość listów, jakie autor Popiołów przez całe życie otrzymywał, przyzna sobie także prawo do zatrzymania dzienników dla siebie. Hanna Mortkowicz-Olczakowa wytłumaczyła to następująco:

J. H o r zels ki, Tragiczny starzec. „Jutro Pracy” 1932, nr 67, z 29 V. Autor, jak widać, sądził, iż Przesmycki był prezesem polskiego Pen Clubu. Nigdy nie był.

Proces literacki o spuściznę po Stefanie Żeromskim. Sześć miesięcy więzienia za zniesławienie Zenona Przesmyckiego. „Kurier Polski” 1932, nr 334, z 3 XII. Jest to chyba najobszerniejsza relacja dziennikarska z procesu, który był w prasie szeroko komentowany. Zob. np. Proces literacki. Miriam-Przesmycki kontra Braun i Horzelski. „Gazeta Warszawska” 1932, nr 370, z 3 XII. - Miriam-Przesmycki i spuścizna Żeromskiego na wokandzie sadu okregowego. „Kurier Poranny” 1932, nr 336, z 3 XII. - Z sali sadowej. Miriam-Przesmycki przeciwko „Zet” i „Jutru Pracy”. „Robotnik” 1932, nr 412, z 3 XII. Wspomniane tutaj Elegie to wydany w roku 1928 (Warszawa) przez W. B orow e go tom zbierający rozsiane w czasopismach bądź niedrukowane utwory literackie i publicystyczne Żeromskiego, zatytułowany Elegie i inne pisma literackie $i$ społeczne. 
Dzienniki, nazwane w testamencie pisarza „pamiętnikami” [...], do roku 1936 [...] znajdowały się w konstancińskiej bibliotece, otoczone największą dyskrecją. Nikt do nich przez ten cały czas nie zaglądał, oprócz mojej matki - Janiny Mortkowiczowej, upoważnionej do tego przez panią Annę Żeromską. Ciekawe, że i w roku 1936, zabierając bibliotekę i inne zbiory, ówczesny prezes Pen Clubu, w myśl życzenia żony, uznał Dzienniki za własność rodziny ${ }^{26}$.

\section{Wolę Stefana Żeromskiego zastąiła zatem wola Anny Żeromskiej.}

Publikowane dotychczas informacje na temat późniejszych - wojennych i powojennych - losów autografów dzienników są skąpe. Wiadomo, że jako depozyt zostały przez panie Żeromskie złożone w Bibliotece Narodowej, że w czasie wojny, wraz Z wieloma innymi dobrami polskiej kultury, zostały wywiezione do Rzeszy. Wiosna 1945 zagarnięte przez Armię Czerwoną i wysłane do ZSRR - wkrótce po wojnie zostały przez władze sowieckie zwrócone Polsce. To jest pewne. Gdy się jednak próbuje losy te poznać dokładniej, gdy się chce ustalić podstawowe fakty: ile tomików obejmował ów depozyt i kiedy został złożony, kiedy i w jakich okolicznościach został przez Niemców zabrany, kiedy tomiki wróciły do Polski i stały się własnością Biblioteki Narodowej, okazuje się, iż odpowiedź na te pytania nie jest łatwa.

Najwcześniejsza informacja na interesujący nas tutaj temat pochodzi z $17 \mathrm{~V}$ 1947. Odpowiadając na jakiś list Jana Parandowskiego, Anna Żeromska napisała wtedy do niego:

Szanowny Panie.

Pamiętnik męża mojego, o ile Pan sobie przypomina, złożony był jako depozyt w Bibliotece Narodowej. W pierwszych dniach powstania oficer SS zażądał wydania sobie całej zawartości kasy pancernej, w której właśnie pamiętnik się znajdował. Rzeczy te zostały jakoby wywiezione do Austrii, ale nasze poszukiwania jak dotąd nie dały rezultatu ${ }^{27}$.

Pierwszy obszerny artykuł naukowy o dziennikach, pióra Andrzeja Wasilewskiego, opublikowany został w roku 1951 w wydanym przez Instytut Badań Literackich zbiorze studiów poświęconych twórczości Żeromskiego. Na temat losów autografów czytamy u Wasilewskiego:

Do czasów ostatniej wojny pamiętniki były w posiadaniu rodziny pisarza; podczas powstania warszawskiego - złożone do depozytu w Bibliotece Narodowej - wpadły w ręce jakiegoś Niemca, który wywiózł je do Austrii. Zdołała je tam odszukać komisja radziecka, rewindykująca zagrabione mienie. W ten sposób uchowały się ostatecznie przed hitlerowskimi podpalaczami i w r. 1945 wróciły do Polski2 ${ }^{28}$.

W roku 1963 podobne informacje podał Kądziela we wstępie do drugiego wydania Dzienników - w ramach Dziet Żeromskiego pod redakcją Pigonia:

Ponieważ przez całą okupację willa Świt w Konstancinie była zajęta przez zmieniające się co pewien czas oddziały Wehrmachtu, spadkobierczynie pisarza uznały za pewniejsze locum Bibliotekę Narodowa, gdzie też tomiki Dzienników złożono w charakterze depozytu. Odtąd dzieliły los innych zbiorów bibliotecznych: wywiezione wraz z najcenniejszymi zasobami przez hitlerowców do Austrii, zostały po zakoń-

Mortkowicz-Olczakowa, op. cit., s. 68-69.

Korespondencja Jana Parandowskiego. T. 51: Y-Z. Bibl. Narodowa, rkps 17693/51.

28 A. W a sil e w s ki, Dziennik Stefana Żeromskiego. W zb.: Stefan Żeromski. Prace wykonane w Zakładzie Historii Literatury Polskiej Epoki Imperializmu IBL pod kierownictwem E. Ko r z e n i e ws ki ej. Warszawa 1951, s. 14. W roku 1953 artykuł ten - w niewielkim stopniu odmieniony - został wydrukowany jako przedmowa na czele pierwszego tomu pierwszego wydania Dzienników. 
czeniu wojny w r. 1945 rewindykowane przez Armię Radziecką, a następnie zwrócone Polsce. Oczywiście nie sposób dziś ustalić, w jakim miejscu tych burzliwych peregrynacji zaginęło sześć tomików z pierwotnej liczby dwudziestu jeden. Równie dobrze mogły przepaść wszystkie ${ }^{29}$.

Najwięcej szczegółów - nie wiadomo skąd czerpanych - na temat okupacyjnych losów autografów podała w swojej książce, w roku 1964, Mortkowicz-Olczakowa, która napisała:

[dzienniki] zostały [...] zdeponowane w Bibliotece Narodowej i zabezpieczone w specjalnym safesie, gdzie znajdowało się także zwinięte płótno Chełmońskiego Kuropatwy i jedna karta $z$ iluminowanej Biblii Królowej Zofii. Paczka z Dziennikami opatrzona była napisem: „Własność Anny Żeromskiej”, i zastrzeżona klauzulą, że Dzienniki nie mogą być drukowane przed upływem 50 lat od śmierci pisarza (to jest przed rokiem 1975). Po wybuchu wojny i zajęciu Warszawy przez Niemców zgłosił się do Biblioteki Narodowej jakiś oficer niemiecki i zażądał otworzenia safesu. Po czym zabrał cała jego zawartośćc ${ }^{30}$.

Znacznie zwieźlej o losach tomików informował Kalendarz życia i twórczości Żeromskiego: „Oddane w czasie powstania warszawskiego do Biblioteki Narodowej, zostały wywiezione do Austrii. Do Biblioteki Narodowej powróciły via ZSRR w 1947 r." 31

Wiele lat później, bo dopiero w roku 1995, na temach autografów wypowiedziała się też Monika Żeromska. W książce zatytułowanej Wspomnienia i podróże napisała, iż jej matka przekazała tomiki dzienników „do Biblioteki Narodowej jeszcze w 1936 roku jako depozyt":

Dalej - wiadomo, co było - a Dzienniki z innymi cennymi rzeczami zostały przez oficera SS zabrane z kasy pancernej Biblioteki Narodowej, od której to kasy profesor Grycz musiał esesmanowi oddać klucze. Potem była długa cisza, ja zostawiałam kartki w punktach poszukiwania rzeczy z rewindykacji, aż jakiś literat czy ktoś w tym rodzaju znalazł Dzienniki w Moskwie i przywiózł je z hukiem do Warszawy ${ }^{32}$.

Wszystkie te dane wypada zweryfikować i skomentować.

W kwestii terminu złożenia depozytu - najmniej wiarygodne wydają się relacje Mortkowicz-Olczakowej i Moniki Żeromskiej. Nie tylko z tego względu, że obie autorki w swych opowieściach wielokrotnie mijały się z prawdą; także dlatego, że przeciwko ich twierdzeniu wytoczyć można niebagatelne argumenty. Po pierwsze: gdyby depozyt został złożony przed rokiem 1939, z pewnością zostałby jakoś formalnie pokwitowany, jakoś odnotowany w dokumentach Biblioteki; byłaby znana dokładna data złożenia, spis lub przynajmniej liczba dostarczonych tomików. Takie pokwitowanie nie istnieje, dzienniki nie figuruja też w zrekonstruowanym przez Danutę Kamolową Wykazie rękopisów Stefana Żeromskiego znajdujacych się w Bibliotece Narodowej przed 1939 r. i w czasie okupacji33. Gdyby - po drugie - depozyt

Kądziela, przedmowa, s. 7 .

Mortkowicz-Olczakowa, op. cit., s. 69.

Stefan Żeromski. Kalendarz życia i twórczości, s. 385.

M. Że romska, Wspomnienia i podróże. Warszawa 1995, s. 23. Warto tutaj zauważyć, że gdy w 1964 roku M. Że r o m s k a (Dzieje rękopisów Żeromskiego. „Poradnik Bibliotekarza” 1964, nr 6. Przedruk w zb.: Walka o dobra kultury. Warszawa 1939-1945. Księga zbiorowa. T. 2. Red. S. L or e n z. Warszawa 1970) omawiała wojenne losy rękopisów ojca, o dziennikach nie wspomniała ani słowem.

D. Ka mo low a, Spuścizna Stefana Żeromskiego w zbiorach rękopiśmiennych Biblioteki Narodowej. „Rocznik Biblioteki Narodowej” 1966. 
został przekazany w roku 1936, zdarzenie takie byłoby zapewne zapamiętane przez któregoś z bibliotekarzy Biblioteki Narodowej; nie zostało jednak zapamiętane. I po trzecie: jeśli w roku 1936 Anna Żeromska nie oddała (ignorując testamentowy zapis) dzienników polskiemu Pen Clubowi, to dlaczego miałaby je przekazać - jako depozyt - Bibliotece Narodowej?

Prawdopodobniejsze wydają się twierdzenia Wasilewskiego i Kądzieli, iż dzienniki trafiły do Biblioteki Narodowej dopiero w czasie wojny, gdy bezpieczeństwo autografów Żeromskiego, przechowywanych do tej pory w Konstancinie, zostało zagrożone; sejfy Biblioteki były przecież znacznie pewniejszym schronem niż konstancińska willa. Monika Żeromska wymienia w swym wspomnieniu nazwisko prof. Józefa Grycza, który musiał oddać klucze od sejfu. Jeśli panie Żeromskie w sprawie depozytu kontaktowały się z prof. Gryczem, to mogły to uczynić najwcześniej w lipcu 1940, bo dopiero wtedy - z nominacji okupacyjnych władz niemieckich i za wiedza polskiego podziemia ${ }^{34}$ - objął on dyrekcję Biblioteki Narodowej (II Oddział Staatsbibliothek Warschau). Jeśli tak istotnie było, to depozyt zapewne nie był oficjalnie przez Bibliotekę kwitowany; nie było po temu ani czasu, ani warunków. Dlatego nie wiemy, ile dokładnie tomików (bo na pewno nie wszystkie) trafiło do bibliotecznych sejfów.

Od roku 1943, kiedy wojska niemieckie zaczęły się cofać przed Armią Czerwoną, a front zbliżał się do Warszawy, polskie kierownictwo Biblioteki Narodowej zainicjowało prace służące zabezpieczeniu zbiorów na wypadek działań wojennych, władze niemieckie zaś - przygotowania do przewiezienia najcenniejszych zbiorów do Rzeszy. Wybuch powstania warszawskiego wstrzymał i zmodyfikował te przygotowania - jednak na krótko. Już w połowie sierpnia 1944, gdy w wyniku niemieckiego ostrzału artyleryjskiego i lotniczych bombardowań miasto płonęło i zmieniało się w ruinę, generał Hermann Fegelein przekazał dowódcy sił niemieckich w Warszawie rozkaz Führera dotyczący ochrony miejscowych dóbr kultury. Do Warszawy przybył z oddziałem żołnierzy porucznik SS Moritz Arnhardt, który miał wywieźć do Rzeszy najcenniejsze zbiory muzealne i biblioteczne - nim miasto zostanie całkowicie zniszczone. Wiadomo, że w Bibliotece Narodowej (wówczas znajdującej się przy ul. Rakowieckiej) Arnhardt pojawił się co najmniej dwukrotnie: 3 i 4 IX 1944; to on był tym oficerem SS, o którym Monika Żeromska napisała we wspomnieniach, że zażądał od prof. Grycza klucza od sejfu.

Na temat tej jego misji zachowało się kilka wiarygodnych informacji.

Jeszcze w roku 1944 prof. Grycz zanotował w swym dzienniczku:

22 VIII [1944] [...]. Cenniejsze rękopisy i stare druki wkładamy do ogniotrwałej kasy. [...]

28 VIII wezwano p. Grodka do Batza, który zażądał pisemnego raportu o władzach, zasobach i najcenniejszych materiałach Biblioteki, której grozi spalenie, a nam wyrzucenie. Przed godz. 17 zgłosiłem się z p. Grodkiem i wręczyłem żądane pismo. Staraliśmy się wykazać wartość zbiorów dla kultury ogólnej. Batz oświadczył, że pismo jest dobrze napisane i że je pośle dalej. [...]

3 IX około godz. 15 zjawił się Obersturmführer Arnhardt $z$ moim pismem i kazał sobie pokazać wymienione tam najcenniejsze zbiory. Oświadczył, że je wywiezie celem zabezpieczenia. Po chwili wrócił z ciężarówką i robotnikami, którzy naładowali 16 skrzyń książkami wilanowskimi, zawartością kasy najcenniejszych zbiorów Biblioteki, a także przyjmowanie i otoczenie opieką prywatnych archiwów i kolekcji. 
(rękopisy, stare druki), kartami katalogowymi, maszynami do pisania oraz zabrali 16 szuflad grafiki wilanowskiej. Podczas ładowania padał deszcz, otwarte szuflady wynoszono tylko nakryte workami. Skrzynia z kasy: BNJP 46, RP St 32.

4 IX. Pakowaliśmy z robotnikami pod nadzorem Arnhardta jak najpospieszniej dalsze książki wilanowskie i wybierane przez nas książki z Biblioteki SGH. Nasza polityka szła w kierunku wydania możliwie jak najwięcej rzeczy, gdyż uważaliśmy, że lepiej je później rewindykować, niż narazić na spalenie, którym ustawicznie nam grożono. Ogółem na 4 ciężarówkach wywieziono 50 skrzyń zbiorów wilanowskich, 2 skrzynie książek z SGH oraz 29 szuflad i 2 bardzo duże skrzynie grafiki. Od robotników dowiedzieliśmy się, że nasze skrzynie wraz z rzeczami z Belwederu mają w zaplombowanych wagonach iść do Wrocławia. Arnhardt przed odejściem obiecał przynieść następnego dnia pokwitowanie, że zabrał nasze zbiory z rozkazu Führera „der Sicherstellung der wertvollsten Kulturgüter” [zabezpieczenia najcenniejszych dóbr kultury] przed całkowitym zniszczeniem Warszawy. Ale więcej się nie pokazał ${ }^{35}$.

O rekwirowanych i wywożonych $z$ Warszawy przez Arnhardta dobrach bibliotecznych pisały także Alodia Kawecka-Gryczowa ${ }^{36}$ i Hanna Łaskarzewska ${ }^{37}$; o zabieraniu przez niego dzieł sztuki z Muzeum Narodowego obszernie opowiedział Stanisław Lorent $z^{38}$.

Zdaniem wybitnego znawcy wojennych losów bibliotek warszawskich, Andrzeja Mężyńskiego, Obersturmführer Arnhardt „wywoził wybrane zbiory do posiadłości swego przełożonego [tj. generała Fegeleina] - zamku Fischhorn w Austrii”. W przypisie do tej informacji dodał: „Do Biblioteki dotarła informacja, że skrzynie wysłano do Wrocławia. W rzeczywistości Arnhardt przesłał je do Austrii i umieścił w zamku Fischhorn"39.

Jeśli Arnhardt wszystkie swe transporty wysłał do Fischhornu, to nie mogło być w nich dzienników Żeromskiego. Fischhorn w pobliżu Salzburga wyzwolony został przez armię amerykańską: zgromadzone tam liczne polskie dzieła sztuki, a także książki i rękopisy pochodzące $z$ różnych bibliotek i muzeów zostały odnalezione i rozpoznane przez porucznika Bohdana T. Urbanowicza, który o swym odkryciu zawiadomił zarówno amerykańskie władze okupacyjne, jak i władze polskie, potem zaś wyszukiwał, inwentaryzował i pakował dzieła sztuki, książki i archiwalia, dzięki czemu już w kwietniu 1946 mogły one wrócić do kraju ${ }^{40}$. Wiadomo natomiast $\mathrm{z}$ całą pewnością, że autografy dzienników Żeromskiego przywiezione zostały do Warszawy latem roku następnego - i to z Moskwy; ich losy potoczyły się zatem inaczej. Prof. Grycz najwyraźniej nie zapamiętał szczegółów ewakuacji rękopisów i niedokładnie poinformował panie Żeromskie o zabraniu dzienników przez

J. G ry c z, Dzienniczek z okresu powstania warszawskiego 1944 r. W zb.: Z zagadnień teorii i praktyki bibliotekarskiej. Studia poświęcone pamięci Józefa Grycza. Wrocław 1961. Przedruk w zb.: Walka o dobra kultury. Warszawa 1939-1945. Ksiega zbiorowa. T. 1, s. 251-252.

A. Ka w e ck a - G ry c z ow a, Ochrona zbiorów Biblioteki Narodowej. W zb.: jw., s. 219-220, 239. Autorka ta, podobnie jak wcześniej A. Żeromska w swym liście do Parandowskiego, jak Wasilewski i Kądziela, twierdziła (s. 222), że wysłany przez Arnhardta transport książek, grafik i rękopisów trafil do Austrii - do Fischhornu.

37 H. Ła s k a r z ew s k a, Straty Okólnika w czasie powstania warszawskiego i po jego upadku. W zb.: Droga do Okólnika 1844-1944. W 160. rocznice powstania Biblioteki Ordynacji Krasińskich i w 60. spalenia bibliotek warszawskich w gmachu BOK na Okólniku. Oprac., posł. H. T c h ó r z e w s ka - Ka b a ta. Warszawa 2005, s. 159-160.

Zob. B. T. U rb a n ow i c z, Dziennik Fischhornu. W zb.: Walka o dobra kultury, t. 2. 
Arnhardta - stąd z pewnością wzięła się powtarzana potem przez wielu badaczy informacja o ich wywiezieniu do Austrii. W istocie zostały one ewakuowane $z$ Warszawy dopiero w końcu listopada 1944, w ramach tzw. akcji pruszkowskiej - i nie do Fischhornu, lecz do Görbitz (polska nazwa: Garbicz) w pobliżu Frankfurtu nad Odrą. Pisze o tym wspominany prof. Mężyński, świadczą o tym także - w sposób nie budzacy wątpliwości - dokumenty zachowane w archiwum Biblioteki Narodowej $^{41}$.

Już po kapitulacji powstańczych władz Warszawy i po ewakuacji ludności cywilnej ekipy polskich muzealników, archiwistów i bibliotekarzy, we współpracy z władzami niemieckimi i pod ich nadzorem, ewakuowały do Rzeszy dobra naszej kultury, w tym także szczególnie wartościowe rękopisy i książki. Teraz w akcji tej uczestniczyli sami Polacy, przekonani, że jest to najpewniejszy, a może nawet jedyny sposób uratowania cennych dzieł i dokumentów, bo gdy Armia Czerwona przypuści szturm na Warszawę, gdy na miasto spadną znowu tysiące pocisków i bomb, nie pozostanie tutaj kamień na kamieniu. Ewakuacją zbiorów bibliotecznych kierował Gustav $\mathrm{Abb}^{42}$; zespołem zaangażowanych w nią polskich bibliotekarzy i muzealników Lorentz. Mężyński pisze o tym tak:

Podczas całej akcji pruszkowskiej zbiory wywieziono w 9 wagonach. Pierwszych pięć skierowano do posiadłości zaprzyjaźnionej z generalnym gubernatorem Hansem Frankiem rodziny von Rieselmannów w Garbiczu. Właśnie Frank polecił to miejsce Gustavowi Abbowi, a ten odwiedził Garbicz w czerwcu 1944 roku. Książki wysłane do Garbicza w okresie od 15 listopada do 2 grudnia 1944 roku wyczerpały możliwość dalszego składowania zbiorów warszawskich w tym majątku. [...] Kiedy okazało się, że Garbicz nie jest przygotowane do przyjęcia następnych transportów z polskimi książkami, 3 wagony zbiorów Abb skierował (5 XII - 16 XII 1944) do Adelina ${ }^{43}$ na Dolnym Śląsku, gdzie złożono już wiele książek ewakuowanych między innymi z Ossolineum i Biblioteki Jagiellońskiej. Ostatni, dziewiąty wagon, wypełniony głównie literatura popularną, został wyekspediowany 17 grudnia do Berlina, pod adres pełnomocnika rządu GG Josefa Taschnera ${ }^{44}$.

Gdy tylko Dolny Śląsk zajęty został przez wojska radzieckie, do Garbicza i Adelina wyruszyły ekipy polskich bibliotekarzy - w misji odnalezienia, rewindykowania i przetransportowania do Warszawy ewakuowanych wcześniej zbiorów. W sierpniu 1945 w Adelinie, w majątku rodziny von Pfeil, grupa kierowana przez Ksawerego Świerkowskiego odnalazła warszawskie książki i w październiku przywiozła je do Warszawy ${ }^{45}$. Wcześniej, bo w maju 1945, podobna wyprawa, pod wodzą Bohdana Korzeniewskiego i Witolda Jabłońskiego, wyruszyła do Garbicza.

Za udostępnienie tych dokumentów i pomoc w ich odnalezieniu podziękowanie zechca przyjąc: Pan Tomasz Makowski - Dyrektor Biblioteki Narodowej, Pani Anna Romaniuk - kierownik Zakładu Rękopisów, Pani Maria Remisz - kierownik Archiwum, oraz Pan Tomas z Mińko, który w poszukiwaniu dokumentów przeprowadził w archiwum skrupulatną i owocną kwerendę.

42 Gustav Abb (1886-1945) był dyrektorem utworzonego przez okupacyjne władze niemieckie Głównego Zarządu Bibliotek w Generalnym Gubernatorstwie.

43 Niemiecka nazwa: Adelsdorf; dzisiejsza polska nazwa: Zagrodno.

44 Mężyńs ki, op. cit., s. 269-270.

45 O wyprawie tej opowiedział jej uczestnik, B. Horodyski (W 16 rocznice pamiętnych dni. Na śladach warszawskiej ksiażki. „Stolica” 1961, nr 3. Przedruk w zb.: Walka o dobra kultury, t. 2). 
W Archiwum Biblioteki Narodowej zachowało się datowane 9 VI 1945 i podpisane przez doc. dra Witolda Jabłońskiego i dra Bohdana Korzeniewskiego obszerne, siedmiostronicowe Sprawozdanie delegatów Ministerstwa Oświaty z wyjazdu do Görbitsch pod Frankfurtem n/Odra i rewindykacji ksiażek z bibliotek warszawskich. Na początku owego sprawozdania napisali oni:

Według informacji niemieckich książki z bibliotek warszawskich ewakuowane po powstaniu skierowane były do Görbitsch w ilości 6 wagonów. W marcu radzieckie władze wojskowe zawiadomiły Ministerstwo Oświaty o odnalezieniu polskich książek w Görbitsch. Dn. 20 III z inicjatywy dr Fleszarowej Ministerstwo Oświaty rozpoczęło akcją rewindykacyjną, delegując do niej dr. Bohdana Korzeniewskiego i doc. dr. Witolda Jabłońskiego. Ambasada Radziecka, do której zwrócono się z prośbą o wizę, odpowiedziała, że na razie dostęp do Görbitsch, jako do miejscowości przyfrontowej, jest niemożliwy. Dopiero 22 IV Ambasada zawiadomiła Ministerstwo, że nie ma już przeszkód dla polskiej akcji rewindykacyjnej w Görbitsch.

Dalej delegaci informowali o wyjeździe z Warszawy 7 V 1945, o przybyciu do Garbicza, o odszukanych książkach i rękopisach, także o uzyskaniu informacji, że stacjonujące tutaj wojsko radzieckie wcześniej odnalazło również książki rosyjskie, które zostały wysłane do Moskwy. W czasie miesięcznego pobytu w Garbiczu delegaci zdołali rozpoznać, spakować i przygotować do przetransportowania do Warszawy 1444 worki książek, 225 wiązek książek, 42 skrzynki z kartkami katalogowymi, a ponadto dwie wielkie skrzynie i 6 worków $\mathrm{z}$ rękopisami. W zakończeniu sprawozdania czytamy:

Pomimo bardzo powściąliwej postawy zarówno władz rosyjskich i miejscowych mieszkańców wobec zapytań delegacji o istotną ilość książek zdeponowanych pierwotnie w Görbitsch i o dalsze ich losy, udało się ustalić następujący przypuszczalny stan rzeczy: Do stacji Bottschow przyszły z Warszawy 4 wagony książek, z czego jeden nie został przyjęty i odesłano go dalej. 3 wagony zostały końmi przewiezione do Görbitsch. Wagony te to na pewno 1-szy i 5-ty, a prawdopodobnie i 4-ty, ale dokładne określenie wymaga szczegółowego sprawdzenia, gdyż spis posiadany przez delegację nie był dostatecznie dokładny. Po odejściu Niemców przez pewien czas książki były w Görbitsch sumiennie strzeżone przez wystawione posterunki, a w oranżerii sięgały one do wysokości $2 \frac{1}{1} 2 \mathrm{~m}$. Później znaczna ich część została wywieziona, najpewniej w pakach, gdyż z 200, wysłanych w pierwszym wagonie, znaleziono w oranżerii tylko resztki 20. Do tego odnoszą się zapewne słowa komendanta wojennego: Russkije knigi my uwiezli. Następnie o książkach pozostawionych lub przeniesionych na strych zapomniano, a pozostałe w oranżerii resztki rękopisów uległy stopniowemu niszczeniu. [...] W każdym razie w przybliżeniu można powiedzieć, że z 3 wagonów wyładowanych w Görbitsch udało się uratować niespełna 2, a pozostałej reszty większa część została wywieziona, a mniejsza, w ilości przeszło tysiąca tomów, zniszczona ${ }^{46}$.

Wykorzystując informacje zawarte w przytoczonym dokumencie, a także inna swą wiedzę o wywiezionych do Garbicza książkach i rękopisach, już 25 VI 1945 dyrektor Biblioteki Narodowej, prof. Stefan Wierczyński ${ }^{47}$, skierował do Departamentu Bibliotek w Ministerstwie Oświaty obszerny wniosek o wystapienie do władz radzieckich o zwrot książek i rękopisów wywiezionych z Garbicza do Moskwy. W końcowej części tego wniosku podsumował sytuację: 
Według doniesienia członków ekspedycji, opartego na zeznaniach lub oświadczeniach osób postronnych, stwierdzić należy:

1) że wojska niemieckie pozostawiły przy swym ustąpieniu wszystkie pomieszczenia, w których znajdowały się zbiory, w stanie nienaruszonym;

2) że jeszcze przez pewien czas (około miesiąca), gdy w zabudowaniach zamkowych mieścił się sowiecki szpital wojskowy - zdeponowane zbiory były nienaruszone;

3) że dopiero po usunięciu szpitala i objęciu gmachów przez liniowe wojska sowieckie - przystapiły te wojska do badania zawartości zdeponowanych skrzyń i worków;

4) że wtedy za decyzją władz wojskowych zabrano i wywieziono - jak brzmiało oświadczenie Komendanta miejscowego - jeden wagon książek.

Ponieważ wśród zbiorów pozostałych w Görbitsch nie znaleziono najcenniejszego materiału, tj. rękopisów i starych druków, przeto wnioskować należy, że zabrano je w owym wywiezionym wagonie. Przypuszczać przy tym trzeba, że na wybór materiału i na decyzję czynników wojskowych co do wywiezienia wpłynąc mogła mylna interpretacja naklejek sygnaturowych oraz pieczęci, które się mieszczą na poszczególnych rękopisach i książkach.

Należy mianowicie wyjaśnić, że rękopisy i książki pochodzące z Biblioteki Załuskich były swego czasu na rozkaz władz carskich wywiezione $z$ Warszawy do Petersburga, gdzie, dostawszy się do tamtejszej Biblioteki Publicznej, zostały zaopatrzone ekslibrisami sygnaturowymi oraz pieczątkami bibliotecznymi tejże Biblioteki ${ }^{48}$ [...]. Jak jednak wiadomo, rząd ludowy ZSRR, pragnąc wyrównać narodowi polskiemu krzywdę kulturalną wyrządzoną mu przez rządy carskie, zwrócił Polsce urzędowo i komisyjnie wszystkie materiały stanowiące ową Bibliotekę Załuskich ${ }^{49}$, po czym materiały te zostały wcielone do polskiej Biblioteki Narodowej. Otóż te właśnie materiały (druki i rękopisy), opatrzone ekslibrisami i pieczątkami Publicznej Biblioteki w Petersburgu, znajdując się w skrzyniach pomieszczonych w Görbitsch, stały się prawdopodobnie przyczyną nieporozumienia, wskutek którego władze wojskowe, uznawszy je za materiały stanowiące własność państwa rosyjskiego, zagrabione przez Niemców, wywiozły je w głąb państwa rosyjskiego.

Jeżeli moje przypuszczenie jest słuszne, przyjąć należy, że sowieckie władze wojskowe, natrafiwszy raz na grupę skrzyń z zawartością, którą uznały z pozorów formalnych za stanowiącą własność Państwa Rosyjskiego, osądziły - bez bliższego badania - także zawartość reszty skrzyń za własność Państwa Rosyjskiego i wysłały wszystkie skrzynie w głąb Związku Radzieckiego. Wobec tego jednak, że - jak wykazałem - materiały pomieszczone w Görbitsch należą bezspornie do Biblioteki Narodowej, proszę o poczynienie odpowiednich kroków dla zbadania tej sprawy i odzyskanie tych rękopisów i druków dla Biblioteki Narodowej ${ }^{50}$.

To w tej partii rękopisów pojechały z Garbicza do Rosji autografy dzienników Żeromskiego.

Dzieła sztuki i dobra kultury zajmowane na terenie Rzeszy przez oddziały radzieckie przewożone były do Rosji do wyznaczonych składnic: m.in. w petersburskim (wówczas leningradzkim) Ermitażu, w moskiewskim Muzeum Sztuk Pięknych

Biblioteka Załuskich - utworzona w pierwszej połowie XVIII wieku przez biskupów braci Józefa i Andrzeja Załuskich, jedna z największych w ówczesnej Europie bibliotek - w 1795 roku zrabowana została przez Rosję; na rozkaz carycy Katarzyny II zbiory Biblioteki wywieziono do Petersburga, gdzie stały się zrębem Cesarskiej Biblioteki Publicznej (dziś noszącej nazwę Rosyjskiej Biblioteki Narodowej).

49 Po przegranej w roku 1920 wojnie $z$ Polska, na mocy traktatu pokojowego w Rydze, Radziecka Rosja została zmuszona m.in. do zwrotu zrabowanych w Polsce dóbr kultury; na tej podstawie w latach 1921-1934 wróciła do kraju także duża część Biblioteki Załuskich, z czasem włączona do Biblioteki Narodowej w Warszawie. Wierczyński wolał w swym piśmie - ze zrozumiałych względów - zwrot Biblioteki Załuskich przedstawić tak, jak przedstawił.

50 Kopia listu Dyrektora Bibl. Narodowej, prof. S. Wierczyńskiego do Ministerstwa Oświaty, z 25 VI 1945. Archiwum Bibl. Narodowej, sygn. 482/16. 
im. Puszkina i - także w Moskwie - w Bibliotece im. Lenina. Transport z Garbicza trafił do tego trzeciego magazynu. W dniu 23 V 1946 Tymczasowy Rząd Jedności Narodowej zawarł $\mathrm{z}$ władzami radzieckimi porozumienie w sprawie wymiany dóbr kultury między Polską a ZSRR ${ }^{51}$; to na podstawie tego porozumienia w rok później, w początkach lipca 1947, wrócił z Moskwy do Polski wielki zbiór dokumentów i rękopisów, w tym i tomiki dzienników Żeromskiego. Formalnie nie był to zwrot rewindykowanych do Polski zabytków naszej kultury, lecz element wymiany takich dóbr między Polską a ZSRR; Związek Radziecki oddawał nam stanowiące jego własność zabytki polskiego piśmiennictwa i w zamian mógł oczekiwać podobnego zachowania strony polskiej. Usłużna prasa reżimowa traktowała ten zwrot niemal jako wspaniałomyślny radziecki dar dla narodu polskiego. Wprawdzie np. „Tygodnik Warszawski” pisał o rewindykacji ${ }^{52}$, ale tygodnik „Odrodzenie” rozpływał się nad szczodrością radzieckich przyjaciół. W jego numerze 29, datowanym 29 VII 1947, pod wspólnym tytułem Skarby kultury wracaja do kraju opublikowane zostały artykuły Jana Dembowskiego i Samuela Fiszmana.

Dembowski rozpoczął swój tekst następująco:

Na wniosek dyrekcji Biblioteki im. Lenina w Moskwie władze radzieckie przekazały Polsce bezcenne materiały książkowe i rękopiśmienne wywiezione przez Niemców z Biblioteki Narodowej i Biblioteki Uniwersytetu Warszawskiego. Przypomnę, że już po raz trzeci Związek Radziecki zwraca nam nasze mienie kulturalne. W roku zeszłym otrzymaliśmy za pośrednictwem Muzeum im. Puszkina wiele polskich obrazów i innych dzieł sztuki. Na początku roku obecnego Centralna Biblioteka Lekarska w Moskwie zwróciła nam zbiór książek stanowiących własność Polskiej Biblioteki w Paryżu, a przywiezionych do Moskwy z Królewca. Jednakże to, co otrzymujemy obecnie, wartością swoją o wiele przewyższa dotychczasowe zwroty. Jest to bardzo różnorodny zbiór materiałów naukowych, którego należyte uporządkowanie wymagałoby dużej pracy. W tej chwili jesteśmy w stanie podać tylko niektóre dane orientacyjne ${ }^{53}$.

Dalej Dembowski wyliczył ważniejsze zwracane rękopisy, wśród nich i autografy Żeromskiego.

Podobnie wypowiadał się Fiszman:

Miłośników książki, dziejopisów i historyków literatury czeka radosna niespodzianka. Wracają bowiem na półki naszych bibliotek skarby zaginione w czasie wojny. Wracają setki pergaminów, tysiące rękopisów, cennych druków, dziesiątki tysięcy książek. Wywiezione przez Niemców w czasie okupacji, rozproszone zostały po różnych miastach i miasteczkach niemieckich wraz z księgozbiorami wywiezio-

51 Zob. K. W róbel-Li p ow a, Rewindykacja archiwaliów polskich z ZSRR $w$ latach 1945-1964. Rozprawa habilitacyjna. Lublin 1982, s. 74-85. - D. M a tel s k i, Losy polskich dóbr kultury w Rosji iZSRR. Próby restytucji. Archiwa - księgozbiory - dzieła sztuki-pomniki. Poznań 2013, s. 168-169. Informację o tym, pt. Rewindykowanie cennych rękopisów $i$ ksiażek, zamieszczono anonimowo w rubryce Przeglad kulturalny (,„ygodnik Warszawski” 1947, nr 28, z 13 VII): „Na mocy podpisanej z Rosją umowy do Polski przywiezione zostaną zrabowane przez Niemców w Bibliotece Narodowej i Bibliotece Uniwersyteckiej Warsz. cenne materiały książkowe (między innymi pierwsze polskie druki z 15 i 16 wieku i pierwsze wydania humanistów) oraz materiały rękopiśmienne (archiwa Kościuszki, Lelewela, Niemcewicza, Kochanowskiego, przywileje królewskie, kronika Kadłubka, diariusze sejmów polskich z 15 i 16 w., listy Voltaire’a, Monteskiusza, Byrona, Kanta, Schillera i innych sławnych ludzi oraz rękopisy wybitnych polskich pisarzy i poetów). Ogółem rewindykowany księgozbiór obejmuje 20000 książek, 1000 książek rzadkich i obszerne archiwum Zamoyskich".

53 J. De mbowski, S. Fis z ma n, Skarby kultury wracaja do kraju. „Odrodzenie” 1947, nr 29, z 29 VII. 
nymi z innych krajów, m.in. ze Związku Radzieckiego. Po wojnie władze radzieckie odszukały zagrabione bogactwa i odesłały do Moskwy. Dopiero tu pracownicy Biblioteki im. Lenina w czasie porządkowania przywiezionych materiałów zauważyli, że na wielu rękopisach i książkach znajdują się stemple polskich bibliotek. Od razu na wstępie należy zaznaczyć, że Biblioteka im. Lenina nie ograniczyła się bynajmniej do stwierdzenia przynależności rękopisów i druków i do ich zwrotu, ale dokonała olbrzymiej pracy uporządkowania całości, odkurzania, dezynfekowania, a nawet restaurowania starych pergaminów.

W kolejnych zdaniach Fiszman, podobnie jak Dembowski, informował o zwracanych rękopisach; wymienił wśród nich także „wszystkie zeszyty Dzienniczka Stefana Żeromskiego" 54 .

W roku 1948 zorganizowana została wystawa tych przywiezionych z Moskwy książek i rękopisów; znalazły się na niej i autografy dzienników. W wydanym wówczas katalogu wystawy, na liście eksponowanych rękopisów pod numerem 77 znalazł się Dzienniczek Stefana Żeromskiego z lat 1882-1890 (14 tomików). BN55. W listopadzie 1948 tych 14 tomików zapisano w księdze akcesji Biblioteki Narodowej pod numerem 4717 jako „zbiory zabezpieczone”. Były to tomiki: I, II, III, VI, IX, XI, XII, XIII, XIV, XV, XVII, XVIII, XIX i XX.

W Bibliotece Narodowej znajdował się wówczas także fragment jeszcze jednego tomiku - obejmującego zapisy z września i pierwszych jedenastu dni października 1891 - w sierpniu 1948 zarejestrowany w księdze akcesji Biblioteki pod numerem 4600 jako Fragment dziennika i oznaczony jako pochodzacy ze „starego zasobu”.

Tomik ten, stanowiący część depozytu złożonego w Bibliotece Narodowej przez panie Żeromskie, został uszkodzony (rozerwany) zapewne w listopadzie 1944, gdy dzienniki, wśród innych rękopisów, wywożone były z Warszawy do Garbicza; jedna jego część pojechała do Rzeszy, druga pozostała w gmachu Biblioteki. Gdy po wojnie porządkowano tam ocalałe zbiory, ta odnaleziona część liczyła 24 kartki: jedna kartkę wypełnioną dziennikowymi zapiskami z 9 i 10 IX 1891, 19 kartek z notatkami rozpoczynającymi się 23 IX i doprowadzonymi do 11 X 1891 oraz 4 kartki puste. To te 24 kartki zarejestrowane zostały niebawem w księdze akcesyjnej Biblioteki Narodowej pod numerem 4600. W tym samym mniej więcej czasie, w maju 1945, gdy Korzeniewski i Jabłoński w Garbiczu identyfikowali, pakowali w worki i przygotowywali do wysłania znajdujące się tutaj jeszcze książki i autografy należące do warszawskich bibliotek, zabrali także pojedyncze rękopisy i ich fragmenty, pochodzące $z$ wcześniej uporządkowanych, a teraz rozproszonych zbiorów; takie fragmenty zdekompletowanego bądź zniszczonego zespołu noszą w języku bibliotekarzy i archiwistów wziętą $\mathrm{z}$ łaciny nazwę dissolutów. W dwóch skrzyniach i sześciu workach rękopisów, przywiezionych wówczas z Garbicza, znajdowały się i dissoluta z Archiwum Zamoyskich, które - po wstępnym rozpoznaniu odzyskanych autografów - w roku 1951 przekazane zostały do Archiwum Głównego Akt Dawnych w Warszawie. Dopiero tutaj - przy dokładniejszym porządkowaniu otrzymanych

55 Katalog wystawy rękopisów i druków wywiezionych przez hitlerowców do Niemiec, uratowanych przez Armię Czerwona i przekazanych Polsce przez Rzad Radziecki. Warszawa 1948, s. 32 . Na końcu katalogu znalazło się 16 tablic $z$ fotokopiami wystawianych rękopisów; dwie z nich (XIII i XIV) prezentują początkowe stronice pierwszego i trzeciego tomiku dzienników. 
materiałów, wyszło na jaw, że wśród owych dissolutów znajduje się także fragment dzienników Żeromskiego: 10 kartek z zapisami od 10 do 23 IX 1891, jak się potem okazało, idealnie wpasowujących się między pierwszą a dwunastą kartkę fragmentu zeszytu odnalezionego „w starym zasobie” Biblioteki Narodowej.

Nie wiadomo, kto i kiedy dokładnie zidentyfikował w Archiwum Akt Dawnych ten przywieziony z Garbicza fragment dziennika; stało się to dopiero w końcu 1954 lub w poczatkach 1955 roku. W kwietniu 1955 o znalezisku poinformowała „Nowa Kultura"56 - i stąd właśnie dowiedziała się o nim dyrekcja Biblioteki Narodowej.

W dniu 12 IV 1955 dyrektor Biblioteki, Władysław Bieńkowski, oficjalnie wystąpił o zwrot autografu do Naczelnej Dyrekcji Archiwów Państwowych w Warsza$w_{i}{ }^{57}$ - i już po kilkunastu dniach fragment dziennika przekazano do Biblioteki z następującym wyjaśnieniem, podpisanym przez Dyrektora Archiwum Głównego Akt Dawnych, Michała Wąsowicza, datowanym 23 IV 1955:

W wykonaniu polecenia Naczelnej Dyrekcji Archiwów Państwowych z dnia 20 kwietnia rb. Archiwum Główne Akt Dawnych przekazuje przy niniejszym fragment Dzienników Żeromskiego odnaleziony wśród dissolutów Archiwum Zamoyskich i prosi o potwierdzenie odbioru. Archiwum Główne od pierwszej chwili odnalezienia wspomnianego fragmentu i rozpoznania go nie miało wattpliwości, iż właściwym miejscem przechowywania tego rękopisu jest Biblioteka Narodowa, gdzie znajdują się zachowane części rękopisu Dzienników Żeromskiego. Jednak, ze względu na interes nauki, Archiwum Główne jeszcze przed przekazaniem odnalezionego fragmentu Bibliotece Narodowej udostępniło go Instytutowi Badań Literackich, który przygotowuje obecnie wydanie III-go tomu Dzienników Żeromskiego. Tom ten, obejmujący również rękopis, $z$ którego pochodzi wspomniany fragment, jest już w druku, a więc włączenie uzupełniającego fragmentu było sprawą niecierpiącą zwłoki. Z tego powodu Archiwum Główne zdecydowało się na udostępnienie rękopisu IBL-owi $\mathrm{z}$ pominięciem drogi formalnej, tj. przed przekazaniem go do Biblioteki Narodowej; stąd też wynikła pewna zwłoka w przekazaniu [... $]^{58}$.

Dopiero teraz, gdy ocalałe fragmenty zostały złączone, Biblioteka Narodowa znalazła się w posiadaniu całej końcowej części tomiku z września i października 1891. Nie wiadomo, ile kartek $\mathrm{z}$ początku tego tomiku przepadło bezpowrotnie; zachował się kompletny tekst dalszej części z zapisami od 9 IX do 11 X 1891.

Tych 15 tomików opublikowanych zostało w pierwszym wydaniu Dzienników w latach 1953-1956.

Dobry klimat dla rewindykacji i zwrotów polskich dóbr kultury z ZSRR trwał niezbyt długo - do roku 1951. Potem strona polska $z$ wnioskami rewindykacyjnymi nie występowała; dopiero odwilż polityczna roku 1956 stworzyła warunki do starań

T. Zi elińs ka, Żeromski $w$ Nałęczowie. (Nieznany fragment dziennika). „Nowa Kultura” 1955, $\mathrm{nr} 15, \mathrm{z} 10 \mathrm{IV}, \mathrm{s}$. 2. Na wstępie autorka stwierdziła: „Nasze zasoby rękopiśmienne przechodziły w czasie wojny nie lada perypetie. Nie trzeba przypominać, jak wiele spośród nich uległo zniszczeniu, ale także niejeden rękopis nieznany lub uznany za zaginiony wychodzi naraz na światło dzienne. Taką niespodziankę zgotował nam fragment dziennika Stefana Żeromskiego odnaleziony niedawno w Archiwum Głównym Akt Dawnych w Warszawie w luźnych papierach porządkowanego Archiwum Zamoyskich. Jaką drogą tam trafił, nie wiadomo. Być może, że znalazł się tu w czasie wędrówki części zasobów archiwalnych z Warszawy do Niemiec”. Dalej Zielińska informuje, jakie wiadomości o Żeromskim przynosi odnaleziony rękopis, i przytacza jego fragmenty.

57 Kopia pisma Dyrektora Bibl. Narodowej, W. Bi e ń k o w s k i e g o, do Naczelnej Dyrekcji Archiwów Państwowych w Warszawie, z 12 IV 1955. Archiwum Bibl. Narodowej, sygn. 482/19. 
o dalsze zwroty. W czerwcu 1956 rządy PRL i ZSRR podpisały nową umowę o współpracy kulturalnej, która zaowocowała oddaniem (jeszcze jesienia 1956) kilkuset obrazów i grafik, także (w grudniu 1956) wielkiej partii archiwaliów, a w październiku 1957 następnym przygotowanym w Bibliotece im. Lenina transportem rękopisów $^{59}$. Zapewne w tym transporcie wrócił do Biblioteki Narodowej jeszcze jeden, piąty tomik dzienników ${ }^{60}$ - w marcu 1958 zapisany w księdze akcesji pod numerem 7395. W kilka lat później tomik ów został włączony do drugiej edycji Dzienników tym razem w ramach edycji Dzieł Żeromskiego pod redakcją Pigonia. Był to ostatni tomik zwrócony przez Rosję, ale nie ostatni, jaki trafił do Biblioteki Narodowej.

Kilkanaście lat później ofiarowany został Bibliotece tomik, w grudniu 1969 zarejestrowany w księdze akcesji pod numerem 9243 jako dar NN, czyli anonimowy ${ }^{61}$. Kądziela, który ten tomik opublikował w roku 1973 pod tytułem Dzienników tom odnaleziony, dotarł do informacji o losach i autografu, i jego ofiarodawcy. Napisał on:

tuż przed wojną tomik ten znajdował się w Gródku Jagiellońskim pod Lwowem. Miał go w swoim posiadaniu niejaki sędzia Gross, od którego pożyczył go inż. Jerzy Stamirowski. Po obu tych ludziach ślad zaginął. Rodzina Jerzego Stamirowskiego, zamieszkała przed wojną i w czasie wojny w Warszawie, podzieliła losy swego miasta. Wysiedlona w 1944 r., wróciła tu dopiero po dwudziestu z górą latach. Przy porządkowaniu rozproszonych pamiątek rodzinnych znalazł się i ten rękopis. Uznany zrazu za rodzaj prywatnego depozytu, został w 1969 r. przekazany przez dr Zofię Stamirowską Bibliotece Narodowej, w przekonaniu, że wobec zbliżającej się do końca publikacji Dzienników Żeromskiego należy go już teraz uznać za własność ogólnonarodową ${ }^{62}$.

To wyjaśnienie opiera się, oczywiście, na rodzinnej legendzie Stamirowskich, która - jak na ogół takie przekazy - nie musi być ścisła. Nie ulega jednak wątpliwości, iż los tego tomiku był inny niż pozostałych. Na pewno w czasie wojny nie trafił on do Biblioteki; w jakimś momencie od zasadniczego korpusu dzienników został odłączony. Kiedy - i przez kogo? Czy zawieruszył się gdzieś, zanim jeszcze wszystkie zachowane tomiki znalazły się w domu pisarza w Konstancinie? Czy został potem pożyczony - czy to sędziemu Grossowi, czy Jerzemu Stamirowskiemu,

Zob. W ró b e l- Li p ow a, op. cit., s. 74-85.

Zdarzenie to odnotowano w sprawozdaniu Zakładu Rękopisów Bibl. Narodowej za rok 1958 (Archiwum Bibl. Narodowej, sygn. 487/19). P.o. kierownika Zakładu, mgr B. Kupść, napisał w tym sprawozdaniu m.in. że „wśród nowych nabytków w r. ub. znalazła się duża grupa rękopisów odzyskanych z dawnych zasobów Biblioteki Narodowej i b. Biblioteki Ordynacji Zamojskiej, utraconych w czasie wojny” i że „w dniu 17 marca r. ub. [tj. 1958] władze archiwalne przekazały Bibliotece rękopisy zwrócone Polsce [...] przez Rząd Radziecki z zasobu rękopisów zabezpieczonych w Niemczech po działaniach wojennych”; wśród tych zwróconych rękopisów wymienił „V tom Dziennika Stefana Żeromskiego".

61 W Archiwum Bibl. Narodowej zachowała się kopia datowanego 5 XII 1969 podziękowania, skierowanego do Z. Stamirowskiej w Pruszkowie (sygn. 53/17/21): „Dyrekcja Biblioteki Narodowej wyraża Pani podziękowanie za pośrednictwo w oddaniu do zbiorów rękopiśmiennych Biblioteki Narodowej 21-go tomiku dziennika Stefana Żeromskiego, który znajdował się dotychczas w rękach prywatnych jako depozyt rodziny Grossów z Gródka Jagiellońskiego, zaginionej w czasie ostatniej wojny. Nieznany w dotychczasowych wydaniach tomik jest bezcennym uzupełnieniem spuścizny wielkiego pisarza, która stanowi przedmiot szczególnej troski i umiłowania całego narodu". 
który mógł znać się z Żeromskim ${ }^{63}$ ? A jeśli został pożyczony - to przez kogo? Przez Żeromskiego? Przez Annę, która uznawała dzienniki za swoją własność?

Po upływie następnych wielu lat, w grudniu 1992, Biblioteka Narodowa nabyła - od Moniki Żeromskiej - tomik opatrzony później numerem 21a; jego losy potoczyły się jeszcze inaczej. Za życia Żeromskiego i potem aż do wojny znajdował się w Konstancinie, nie wszedł jednak w skład depozytu złożonego w Bibliotece Narodowej i nie odbył podróży przez Rzeszę Niemiecką i Rosję. Być może, błędnie został uznany przez spadkobierczynie za notatnik bez większej wartości i - tak przed wojna, jak po wojnie - dzielił los takich notatników. Dopiero gdy w latach osiemdziesiątych XX wieku rozpoczynała się edycja Pism zebranych Żeromskiego i gdy jej redaktor, prof. Zbigniew Goliński, identyfikował i opisywał wszystkie znajdujące się w Konstancinie autografy, zorientował się, że jest to kolejny tomik Dzienników. Jego fragment, zawierający opis milczącej manifestacji warszawiaków w dniu $3 \mathrm{~V}$ 1891, tj. w setną rocznicę Konstytucji, Goliński opublikował w wychodzącym wówczas tygodniku „Potop”64, a w roku 2000, wraz ze Zdzisławem Jerzym Adamczykiem, wydał ten tomik w Kielcach ${ }^{65}$.

Historia tomiku jest dość prosta, ale i tutaj nie wszystko jest jasne. Wydaje się, że znacznie wcześniej, może jeszcze przed wojną, właściwie rozpoznała go Mortkowicz-Olczakowa, która wszakże nie stwierdziła, że jest to jeden z tomików dziennika. W artykule Jak pisał Żeromski. (Z osobistych wspomnień), wydrukowanym w końcu 1950 roku w „Przekroju”, opowiadała o tym, iż Żeromski miał zwyczaj notowania w małych zeszycikach spostrzeżeń o ludziach i zdarzeniach, cytatów z przeczytanych książek itp., i jako przykład takiego zeszyciku podała „notatnik nałęczowski z r. 1891", w którym -

obok wynurzeń czysto osobistych, charakterystyki Faustyny Morzyckiej [...] znajdują się sprawozdania z pobytu w Warszawie, wypiski z listów Zygmunta Wasilewskiego, a obok notatki i cytaty z czytanych książek Heinego, Musseta, Szczedrina, Lama, formuły geometrii Euklidesa, a nawet Schlegla Przyczynek do określenia stopy wartości dodatkowej66.

Kiedy jednak w 1954 roku Kądziela listownie poprosił Mortkowicz-Olczakową, by uściśliła informacje o owym zeszyciku, odpowiedziała, iż „wzmianka” w jej artykule „pochodzi z zapiski zrobionej na podstawie przedwojennych jeszcze kontaktów z rękopisami Żeromskiego, do których wówczas miałam dostęp"; tę jej odpowiedź Kądziela opublikował ${ }^{67}$. Gdy w roku 1964 autorka przygotowywała swą obszerną

Inż. J e r zy Sta mirow s ki (1873-1943) - publicysta i działacz spółdzielczy - w latach 1918-1932 był starosta powiatu olkuskiego i z tej racji aktywnie uczestniczył w organizowaniu w Olkuszu w maju 1923 ogólnopolskich uroczystości ku czci poległego w powstaniu styczniowym i pochowanego w tym mieście Francesca Nulla. W biogramie Stamirowskiego w Polskim słowniku biograficznym (T. 41. Warszawa 2002, s. 504) napisano, że w czasie tych obchodów „przemawiał - obok m.in. Stefana Żeromskiego". Nie udało się ustalić, czy na pewno znali się i kontaktowali osobiście, jednak na pewno obracali się - przynajmniej wówczas - w tym samym kręgu spraw i ludzi.

64 S. Żerom s ki, Setna rocznica Konstytucji majowej. (Nieznane fragmenty „Dziennika”). „Potop” 1991, nr 2/3, s. 10-11.

65 Że romski, Dziennik z wiosny 1891 roku, s. 65.

66 H. Mortkowi cz-O lc zakow a, Jak pisał Żeromski. (Z osobistych wspomnień). „Przekrój” 1950, nr 296, s. 7 .

67 Kądziela, przypisy w: Żeroms ki, Dzienniki, t. 7, s. 445-446. 
książkę biograficzną O Stefanie Żeromskim, także tutaj notatnikowi z roku 1891 poświęciła spory ustęp, zacytowała nawet niewielki jego fragment, zaznaczając znowu, iż posługuje się „dawnym zapisem sprzed lat”; teraz twierdziła, iż notatnik „został zapisany w okresie przerwy w prowadzeniu Dzienników i stanowi pewną ich odmianę" 68 . Konsekwentnie więc (i trochę wykrętnie) utrzymywała, że nie był to jeszcze jeden tomik dziennika, chociaż nim właśnie był.

W miarę odnajdowania się kolejnych notesów-autografów zmieniały się obliczenia, ile takich notesów Żeromski zapisał, zmieniała się także numeracja niektórych tomików. Przez wiele lat utrzymywało się przekonanie, iż komplet dzienników liczył 21 tomików; tak w roku 1953 informował Wasilewski w przedmowie do pierwszego wydania, podobnie w roku 1961 pisał Kądziela w przedmowie do wydania drugiego. Gdy w roku 1969 do Biblioteki Narodowej trafił tomik opublikowany potem jako Dzienników tom odnaleziony, Kądziela zmienił zdanie i w przedmowie do tego tomu twierdził, iż tomików było 24 czy nawet 25; od kiedy zaś w roku 1991 Goliński rozpoznał tomik ogłoszony następnie drukiem jako Dziennik z wiosny 1891 roku, można sądzić, iż notatników $z$ dziennikowymi zapisami Żeromskiego było co najmniej 26, a ocalało i znalazło się w zbiorach Biblioteki Narodowej - 18:

\begin{tabular}{|c|c|c|c|c|}
\hline $\begin{array}{l}\text { Numer } \\
\text { tomiku }\end{array}$ & Daty zapisów & Liczba kart & $\begin{array}{c}\text { Numer w księdze } \\
\text { akcesji Bibl. } \\
\text { Narodowej }\end{array}$ & $\begin{array}{l}\text { Sygnatura Bibl. } \\
\text { Narodowej }\end{array}$ \\
\hline I & 19 V 1882 - 15 XII 1882 & 87 & 4717 & I.7584 t. 1 \\
\hline II & 16 XII 1882 - 1 IX 1883 & 152 & 4717 & I.7584 t. 2 \\
\hline III & 2 IX 1883 - 1 IV 1884 & 123 & 4717 & I.7584 t. 3 \\
\hline $\mathrm{V}$ & 14 X 1884 - 11 IV 1885 & 170 & 7395 & I. 7584 t. 5 \\
\hline VI & 6 V $1885-24$ X 1885 & 223 & 4717 & I.7584 t. 6 \\
\hline IX & 21 V 1886 - 13 VIII 1886 & 115 & 4717 & I.7584 t. 9 \\
\hline $\mathrm{XI}$ & 18 XI 1886 - 26 II 1887 & 180 & 4717 & I.7584 t. 11 \\
\hline XII & 27 II $1887-29$ V 1887 & 108 & 4717 & I.7584 t. 12 \\
\hline XIII & 1 VI $1887-8$ VII 1887 & 95 & 4717 & I.7584 t. 13 \\
\hline XIV & 17 VII 1887 - 26 VIII 1887 & 104 & 4717 & I.7584 t. 14 \\
\hline $\mathrm{XV}$ & 29 VIII 1887 - 1 XII 1887 & 133 & 4717 & I.7584 t. 15 \\
\hline XVII & 29 II 1888 - 11 VII 1888 & 131 & 4717 & I.7584 t. 17 \\
\hline XVIII & 17 VII 1888 - 21 XI 1888 & 120 & 4717 & I.7584 t. 18 \\
\hline XIX & 23 XI 1888 - 23 VI 1889 & 162 & 4717 & I.7584 t. 19 \\
\hline $\mathrm{XX}$ & 16 VII 1889 - 31 V 1890 & 105 & 4717 & I. 7584 t. 20 \\
\hline XXI & 10 VI $1890-18$ X 1890 & 171 & 9243 & I. 7584 t. 21 \\
\hline XXIII & 8 IV 1891 - 23 V 1891 & 61 & 13666 & I.7584 t. $21 \mathrm{a}$ \\
\hline $\mathrm{XXV}$ & 9 IX $1891-11$ X 1891 & 34 & 4600 & I.7584 t. 22 \\
\hline
\end{tabular}


Nie zachowały się:

tomik IV - obejmujący okres od początków kwietnia do połowy października 1884, kiedy dwudziestoletni Żeromski jest (powtórnie) uczniem szóstej klasy kieleckiego gimnazjum, uzyskuje promocję do klasy siódmej, a w wakacje wyjeżdża z macochą do Mińska Mazowieckiego w gościnę do jej młodszej siostry, Heleny z Zeitheimów Radziszewskiej, żony tamtejszego naczelnika stacji kolejowej; wróci $z$ Mińska zakochany w Helenie;

tomiki VII i VIII - z okresu od połowy października 1885 do połowy maja 1886 , a zatem $\mathrm{z}$ roku szkolnego, w którym Żeromski uczęszcza do klasy ósmej; przygotowuje się wówczas do matury, rozważa, co będzie robił po ukończeniu szkoły, i ciągle zakochany jest w Helenie Radziszewskiej; o tomiku VIII wiadomo nieco więcej, na początku bowiem tomiku IX, pod data 14 VI 1886, Żeromski zanotował o Helenie: "Chciałem, by mną wzgardziła, więc dałem jej do czytania dziennik poprzedni, pokazałem notatkę $\mathrm{z}$ odwiedzin u prostytutki, opowiedziałem chorobę nawet za czarnymi może farbami, słowem, odmalowałem tę śmieszną niznotę, jaka jestem";

tomik X - z zapisami od połowy sierpnia do połowy listopada 1886, tj. z okresu, kiedy Żeromski, odstapiwszy od zdawania egzaminu maturalnego i zapisawszy się na studia weterynaryjne w Warszawie, rozpoczyna studenckie życie;

tomik XVI - z okresu od grudnia 1887 do końca lutego 1888, gdy Żeromski przebywa w Warszawie, utrzymuje się $z$ udzielania korepetycji, bieduje i głoduje;

tomik XXII - z zapisami datowanymi od połowy października 1890 do początków kwietnia 1891, gdy Żeromski zamieszkuje w Nałęczowie, zatrudniony przez inż. Michała Górskiego jako nauczyciel domowy jego dzieci, i gdy zaznajamia się ze środowiskiem inteligencji nałęczowskiej69;

tomik XXIV i początkowa część tomiku XXV - z okresu od końca maja do początków września 1891, tj. z ostatnich tygodni pobytu Żeromskiego w Nałęczowie, gdy bliżej poznaje się on $\mathrm{z}$ Oktawią Rodkiewiczową i gdy rodzi się nowe ważne uczucie;

tomik XXVI - z zapisami obejmującymi ostatnie tygodnie 1891 i pierwsze miesiące 1892 roku, kiedy (po udanym debiucie literackim i zakończeniu guwernersko-korepetytorskiej pracy w Nałęczowie) Żeromski wyjeżdża w pierwszą dłuższą podróż zagraniczna, najpierw do Galicji (do Krakowa, Lwowa i Zakopanego), potem (przez Austrię) do Szwajcarii i w czasie tej podróży przestaje dziennik prowadzić.

Pora wrócić do postawionego na poczatku pytania: w jakich okolicznościach i dlaczego aż tak wiele tomików przepadło?

W roku 1963, zreferowawszy w przedmowie do drugiego wydania Dzienników wojenne i powojenne losy autografów, Kądziela napisał, iż „nie sposób [...] ustalić, w jakim miejscu tych burzliwych peregrynacji zaginęło sześć tomików z pierwotnej liczby dwudziestu jeden"70, sądził więc wówczas, iż wszystkie niezachowane tomiki zawieruszyły się i przepadły w okresie wojny i późniejszych tułaczek autografów;

69 Przyjmujemy, że zapisy z okresu prawie pół roku mieściły się w jednym notesie, równie dobrze mogły jednak wypełniać dwa notesy mniejsze objętościowo. Dlatego mówimy tutaj o „co najmniej” 26 tomikach.

70 Kądziela, przedmowa, s. 7. 
potem nikt już chyba na temat nieodnalezionych tomików dziennika się nie wypowiadał. Dziś wiemy, że tamta diagnoza Kądzieli nie była trafna, że wydarzeń i sytuacji, w których autografy dziennika mogły zaginąć lub ulec zniszczeniu, było znacznie więcej.

Po tym, jak w roku 1969 do Biblioteki Narodowej trafił tomik zwrócony przez Stamirowską, nie ulega wątpliwości, że przed rokiem 1939 jeden notes z zapiskami diarystycznymi znajdował się poza Konstancinem, w rękach sędziego Grossa albo inżyniera Stamirowskiego. Czy ten tomik zrabowany został lub skradziony - czy może wypożyczony? A jeśli wypożyczony - to przez kogo? I czy to był jedyny tomik odłączony przed wojna od całego zbioru?

Po tym, jak Goliński w jednym z notesów Żeromskiego znajdujących się w Konstancinie rozpoznał autograf dziennika $z$ wiosny 1891 , wiadomo, że w czasie wojny do depozytu w Bibliotece Narodowej trafily nie wszystkie tomiki pozostające w rękach pań Żeromskich. Czy w Konstancinie zaplątał się tylko ten jeden?

I trzeba koniecznie postawić inne jeszcze pytanie: czy jakiś tomik albo jakieś tomiki mogły zostać zniszczone - świadomie i celowo - bądź to przez Żeromskiego, bądź przez kogoś $\mathrm{z}$ jego bliskich?

Wydaje się, że on sam mógł zniszczyć tomik ostatni, z końca 1891 i początków 1892 roku, „zdegradowany do rzędu notesu”, a w końcu „zarzucony”. Jeśli więcej w nim było „notesu” niż „dziennika”, to Żeromski był w stanie tak postapić. Czy jakiś tomik lub jakieś tomiki zostały zniszczone także $z$ tego powodu, że naruszały czyjeś dobra osobiste? Że np. kompromitowałyby bohaterki opowiadanych w dzienniku romansów?

Jak wiemy, Żeromski - jeszcze w czasie, gdy swój dziennik prowadził - parokrotnie bliski był takiej decyzji. Latem 1887, gdy przebywał „na kondycji” w Szulmierzu, gdzie szczególnie doskwierała mu samotność, pod datą 23 VII napisał w dzienniku:

Gdybym umierał - nie miałbym komu zostawić moich dzienników. Nie ma nikogo, kto by je przeczytał od deski do deski... Matki nie mam... Pani Helena? - Wycięłaby rzeczy uwłaczające jej miłości własnej, oskarżające ją... A reszty by i nie czytała może. Trzeba będzie spalić dzienniczki (jeżeli się nie ożenię).

Trzy lata później, gdy przebywał (również „na kondycji”) w Łysowie na Podlasiu i gdy wdał się w romans - jednocześnie z dwiema siostrami - z panią Anielą i panią Natalią, po jakiejś awanturze i scenie zazdrości ze strony starszej z nich także myślał o zniszczeniu dziennika. Pod datą 17 VII 1890 zanotował:

Postanowiłem [...] spalić moje dzienniki, listy, które skompromitować by mogły moje dawne kochanki - Helenę, Helenkę, Natusię samą... Wróciłem do domu w nocy i zabrałem się gorączkowo do wyszukiwania listów, nagle zawołano mię.

Takie postanowienia, podejmowane pod wpływem emocji, przemijały - nie czyniąc chyba dziennikom żadnej szkody. Po latach, gdy emocje wyblakły, autor tym mniej miał powodów, by jakieś tomiki zniszczyć.

Wydaje się też mało prawdopodobne, by jakieś notatniki mogły zostać zniszczone przez bohaterki romansów Żeromskiego, chociaż wykluczyć tego nie sposób, zwłaszcza jeśli się zważy, że - po pierwsze - zaginęły głównie tomiki opowiadające o związku Żeromskiego z Heleną Radziszewska, a potem z Oktawią Rodkiewiczową 
oraz że - po drugie - Żeromski dawał swoje dzienniki owym „bohaterkom” do czytania, że taka praktyka była nawet elementem jego strategii podbojów miłosnych. Można ją obserwować już w najwcześniejszym tomiku z roku 1882, gdy 18-letni diarysta zwierza się dziennikowi ze swoich uczuć do młodszej o kilka miesięcy Ludwiki Borkowskiej, a następnie pożycza jej dziennik, by mogła go czytać, komentować, wykreślać pewne wyrazy, dopisywać swoje uwagi. Podobnie autor zachowuje się i potem, w okresie długotrwałego romansu z Heleną Radziszewską; również ona ma dostęp do tomików, w których związek ich jest przedstawiany, i również ona wpisuje do dziennika - obszerniejsze niż jej poprzedniczka - refleksje i wyznania. Znacznie rozleglejsze niż w tomiku I są w tych tomikach także - ubytki tekstu. Oto kilka przykładów takich ubytków:

Pod data 7 X 1885, gdzie Żeromski zwierza się, jak miłość do Heleny zawładnęła jego życiem, najpierw zamazane zostały aż do zupełnej nieczytelności dwa wiersze tekstu, a zaraz potem wydarta obustronnie zapisana karta. W zapisie z $14 \mathrm{VI}$ 1886 po słowach: „Wczoraj [Helena] powiedziała mi, że doznaje symptomów... ciąży. Tak - to nic innego. Wiadomość tego rodzaju byłaby" - również wycięta jest obustronnie zapisana karta. W zapisie pod data 4 IX 1887, gdzie Żeromski skarży się, iż przedwczoraj nikt nie pamiętał o jego imieninach, nawet Helena, która dwa tygodnie wcześniej zapewniała go w liście, że nie może sobie wyobrazić życia bez niego - usunięte są dwie obustronnie zapisane karty. W zapisie z 21 VI 1888, gdzie autor usiłuje opisać ciało półnagiej Heleny - wydarta została kartka.

Te ubytki tekstu pojawiają się, jak widać, w sytuacjach, gdy zakochany autor dziennika wypowiada żale, pretensje albo jakieś opinie krytyczne o Helenie lub gdy, pisząc pean na temat piękna jej ciała, nie zachowuje szczególnej dyskrecji. Niewykluczone, że to "ciotunia Helena” usunęła fragmenty zbyt, jej zdaniem, drastyczne albo krytyczne ${ }^{71}$. Ale nawet jeśli to ona - choćby bez przyzwolenia Żeromskiego wycięła lub wydarła $z$ dziennika kilka kartek, to czy posunęłaby się do zniszczenia jakiegoś tomiku w całości? I czy Żeromski takiej straty by nie zauważył?

I jeszcze słowo o Oktawii Rodkiewiczowej, i o utrzymującej się legendzie, iż przed zawarciem małżeństwa Żeromski dał jej do przeczytania swe dzienniki oraz że ich lektura, jak napisała Mortkowicz-Olczakowa, „odsunęła [...] na rok termin ślubu z Żeromskim, tak bardzo przeraziła ją i zabolała ich treść"72. Ta opinia o odłożeniu terminu ślubu ze względu na zgorszenie czy oburzenie spowodowane zaznajomieniem się $\mathrm{z}$ treścią dzienników, powtarzana w innych pracach o młodości autora, ma, być może, swoje źródło w zanotowanej przez Wacława Borowego jego rozmowie z Oktawią Żeromską odbytej w dniu 23 IX 1927; dowiedział się on wówczas od niej, iż „kiedy się mieli pobrać, dał jej Żeromski do przeczytania swój dziennik. Nic mu

71 Bywały i inne - podobnej natury - ubytki w tekście. Gdy latem 1887 Żeromski przebywał „na kondycji” w Szulmierzu w Ciechanowskiem, zawzięcie flirtował z mieszkającą tam nie znaną nam z nazwiska panną Bronisławą. Obcałowywał ją, gdy tylko nadarzyła się okazja - i opisywał te zaloty w dzienniku. W dniu 22 VIII 1887 zauważył, że z dziennika wydarta została kartka z zapisem z 1 VIII 1887, gdzie - jak stwierdził - „była mowa o którymś ze spotkań z B. Ona dziś rano była w moim pokoju. Wycałowałem ją i poszedłem na lekcje, zostawiając dziennik schowany jak zwykle w tłomoczku. A więc to ona czytała i wyjęła tę kartkę! Jestem strasznie zły! Nie mogę jej tego powiedzieć, naturalnie, ale... wycałuję ja jutro tak, że popamięta!"

M o r t k ow i c z-O lc z a k ow a, O Stefanie Żeromskim, s. 68. 
nie mogła zarzucić, ale ją wiele raziło: opis np. biedy studenckiej i schadzek z mężatkami. O tym z obrzydzeniem czytała"73. Zarazem mówiła wówczas Borowemu, iż wielbiła Żeromskiego „Za szczerość i otwartość”.

Ich uczucie narodziło się jesienią 1891, a w pierwszych dniach roku następnego - istotnie - rozstali się na ponad 5 miesięcy; Żeromski - młody człowiek bez matury, bez wyuczonego zawodu, na domiar złego jeszcze zagrożony gruźlica - pojechał do Krakowa, Lwowa i Zakopanego, by się leczyć, kształcić i szukać pracy; to niemal półroczne rozstanie miało być także próbą trwałości ich uczucia, próbą, na którą oboje przystali. Czas rozłąki świetnie znamy z listów, jakie Żeromski co kilka dni wysyłał do Nałęczowa. Nie ma w tej korespondencji niczego, co mogłoby potwierdzić przytoczoną wcześniej opinię Mortkowicz-Olczakowej. Nic nie wiadomo także, by Oktawia w jakikolwiek sposób ingerowała w tekst zachowanych tomików dziennika lub by przyczyniła się do zniszczenia któregoś autografu. I nie odkładała o rok ślubu. W dniu 3 IX 1892 była już żoną Żeromskiego.

Okoliczności zaginięcia ośmiu tomików pozostają zagadką - być może na zawsze.

\author{
Abstract \\ ZDZISŁAW JERZY ADAMCZYK Jan Kochanowski University, Kielce
}

BEFORE THE NEW EDITION OF STEFAN ŻEROMSKI'S DIARIES: STORIES OF MANUSCRIPTS

The article informs about the history of Stefan Żeromski's diary's manuscripts from the moment the diary started its development, namely from May 1882 until December 1992, when the last of the existing volumes reached the National Library. The history proves to be turbulent since out of at least 26 notes of the diary's contents only 18 survived to the present. The author of the paper accessed many unknown to date library documents, thus he rectifies the numerous mistakes recorded in the scientific material and recollects that in his last will written by the end of his life Żeromski presented his diaries to Polish PEN Club as well as that the inheritress, Anna Żeromska and Monika Żeromska, did not comply with that will: they kept the manuscripts for themselves and regarded them as their private property. This issue became the basis for complications and dispute when in the year 1947 prof. Wacław Borowy started preparing the edition of Dzienniki (Diaries). In the final part the author considers when and in which circumstances as many as at least 8 volumes might have been lost or destroyed.

W. B o r o wy, Rozmowy i listy o Żeromskim. 1. Pani Oktawia Żeromska. W: OŻeromskim. Rozprawy i szkice. Oprac. Z. St ef a n ow ska. Warszawa 1960, s. 249. 